\title{
Evaluasi Deteksi Smell Code dan Anti Pattern pada Aplikasi Berbasis Java
}

\author{
http://dx.doi.org/10.28932/jutisi.v5i3.1981 \\ Sendy Ferdian Sujadi $\bowtie \# 1$

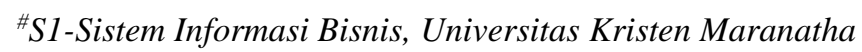 \\ Jl. Prof. drg. Surya Sumantri No. 65, Bandung \\ ${ }^{1}$ sendy. fsdit.maranatha.edu
}

\begin{abstract}
This paper presents an evaluation result of smell code and anti-pattern detection in Java based application development. The main objective to be achieved in this research is to determine the proper way in the detection of smell code and anti-pattern in the development of Java based software, and to evaluate the impact of using code inspection tools and software metrics to refactoring code in Java based software development. Smell code to be detected in this research is Long Parameter List, Large Class, Lazy Class, Feature Envy, Long Method, and Dead Code. Anti-pattern that will be detected is The Blob / God Class and Lava Flow. The selection of smell code and anti-pattern is based on the definition, characteristics, detection factor, and software metrics. To support the research process is done through the evaluation stage of a case study Java based application as a sample for inspection of code for the detection of smell code and anti-pattern and calculation software metrics. Case studies of selected applications as sample applications are ECommerce applications with functional master data management of goods and customers as well as management of sales and payment transactions. The detection of the smell code and anti-pattern on the case study is done in stages so it can be determined whether or not to refactor. As well as ensuring the technique of making the program better fit the characteristics and rules of object-oriented programming.
\end{abstract}

Keywords - Java; anti-pattern; smell code; software metrics; refactoring

\section{Pendahuluan}

Seiring bertambahnya kompleksitas kelas, semakin sulit bagi pengembang baru untuk beradaptasi dengan pengembangan perangkat lunak, sehingga biaya perangkat lunak meningkat. Oleh karena itu, penting untuk menghasilkan kode yang sempurna dan mudah dimengerti [1]. Pengembang sering kali tidak memperhatikan kaidah bahasa pemrograman yang baik yang dapat menghasilkan smell code ataupun sering sekali menggunakan konsep anti pattern dikarenakan terfokus pada hasil fungsionalitas yang harus dicapai pada waktu yang sempit. Hal seperti ini yang menyebabkan kemungkinan implementasi yang buruk dan ketidaksempurnaan kode. Oleh karena itu perlu dilakukan inspeksi terhadap kode yang dirancang dengan buruk secara otomatis agar dapat dilakukan refactoring agar menghasilkan kode dengan rancangan yang baik.

Pemeriksaan kode hanyalah pendekatan di tingkat kode namun menjanjikan untuk mendeteksi kemungkinan kesalahan dalam perangkat lunak [2]. Alat untuk pemeriksaan kode [3] untuk berbagai bahasa pemrograman telah dikembangkan dan banyak digunakan untuk real project. Sebagian besar alat inspeksi kode berguna untuk mendeteksi kesalahan dalam pola yang telah ditentukan seperti CheckStyle [4], PMD [5], Jdeodorant [6], dan Dead Code Detector.

Fowler [7] menyarankan konsep smell code adalah struktur yang perlu dikeluarkan dari kode sumber oleh refactoring untuk meningkatkan kemampuan pemeliharaan perangkat lunak. Smell code didefinisikan dan diatur secara informal. Smell code itu sendiri bukanlah masalah tapi merupakan pertanda adanya masalah. Ini menunjukkan struktur dan kualitas produk perangkat lunak yang buruk. Smell code tidak sama dengan kesalahan sintaks atau peringatan kompilator. Smell code adalah indikasi buruknya disain program atau praktik pemrograman yang buruk. Smell code bukanlah kesalahan, tapi bisa membuat proyek perangkat lunak sulit dikembangkan dan dipelihara saat program membutuhkan modifikasi. Smell code bisa dilepas dengan menerapkan metode refactoring. Smell code adalah struktur program anomali yang mungkin menunjukkan masalah pemeliharaan perangkat lunak. Smell code mempengaruhi unit kode yang berbeda, seperti kelas dan method.

Anti-pattern [8] adalah solusi yang buruk untuk masalah desain yang berulang. Anti-pattern terjadi pada sistem berorientasi objek saat pengembang perangkat lunak tidak menggunakan saat merancang dan menerapkan kelas sistem mereka. Beberapa studi empiris telah menyoroti bahwa antipattern memiliki dampak negatif pada pemahaman dan maintenance sistem perangkat lunak. Akibatnya, identifikasi anti-pattern baru-baru ini mendapat perhatian dari para peneliti dan praktisi yang telah mengajukan berbagai pendekatan untuk mendeteksi anti-pattern. 
Manajemen proses yang berhasil memerlukan perencanaan, pengukuran, dan kontrol. Dalam pengembangan program, persyaratan ini diterjemahkan ke dalam mendefinisikan proses pemrograman dalam serangkaian operasi, setiap operasi memiliki kriteria keluaran sendiri. Selanjutnya harus ada beberapa alat untuk mengukur kelengkapan produk pada setiap titik perkembangannya dengan inspeksi atau pengujian. Dan akhirnya, data terukur harus digunakan untuk mengendalikan proses. Pendekatan ini tidak hanya secara konseptual, namun telah berhasil diterapkan dalam beberapa proyek pemrograman yang mencakup sistem dan aplikasi pemrograman, baik besar maupun kecil. Hal ini mengaktifkan prediktabilitas yang lebih tinggi daripada cara lain dan penggunaan inspeksi telah meningkatkan produktivitas dan kualitas produk [9].

Disiplin iron-clad pada semua peraturan, yang dapat menghambat kerja pemrograman, tidak diperlukan, namun harus ada pemahaman yang jelas tentang fleksibilitas (atau ketidak lengkapan) dari masing-masing peraturan yang diterapkan pada berbagai aspek proyek. Contoh fleksibilitas mungkin menghapuskan aturan bahwa semua jalur utama akan diuji untuk kasus di mana pengujian berulang terhadap jalur yang diberikan secara logis tidak lebih dari menambahkan biaya. Contoh ketidaksempurnaan yang perlu adalah bahwa semua kode harus diperiksa. Prasyarat manajemen proses adalah serangkaian operasi yang jelas dalam prosesnya [9].

Analisis dan desain perangkat lunak berorientasi objek (OOAD) memberikan banyak manfaat seperti reusabilitas, penguraian masalah menjadi objek yang mudah dipahami dan membantu modifikasi masa depan. Namun siklus pengembangan perangkat lunak OOAD tidak lebih mudah daripada pendekatan prosedural yang khas. Oleh karena itu, perlu memberikan panduan yang dapat diandalkan yang dapat diikuti untuk membantu memastikan praktik pemrograman berorientasi objek yang baik dan menulis kode yang dapat diandalkan. Metrik pemrograman berorientasi objek adalah aspek yang harus dipertimbangkan. Metrik menjadi seperangkat standar yang dengannya seseorang dapat mengukur keefektifan teknik Analisis berorientasi objek dalam perancangan suatu sistem. Banyak metrik yang berbeda telah diusulkan untuk sistem berorientasi objek. Metrik berorientasi objek mengukur struktur prinsip yang, jika tidak dirancang dengan benar, berdampak negatif pada atribut kualitas desain dan kode. Metrik berorientasi objek yang ada terutama diterapkan pada konsep kelas, kopling, dan pewarisan [10].

Refactorings [7] adalah perubahan struktural yang dilakukan pada program yang melestarikan semantik program. Sementara banyak karya [7] [11] melihat bagaimana refactoring dapat memperbaiki struktur dan desain sebuah program, karya ini berfokus pada edisi kedua, yaitu bagaimana memeriksa bahwa perubahan tersebut adalah pelestarian semantik. Pelestarian perilaku penting karena jika tidak terjamin, program bisa menghasilkan hasil yang berbeda setelah terjadi perubahan. Refactoring, jika diterapkan dengan benar, sangat ideal untuk evolusi perangkat lunak, karena sudah diketahui bahwa tidak ada bug baru yang diperkenalkan.

Adapun rumusan masalah yang akan dibahas, yaitu: Bagaimana menentukan cara yang tepat untuk pendeteksian smell code dan anti-pattern pada pengembangan perangkat lunak berbasis Java dan Seberapa besar dampak penggunaan code inspection tools dan software metrics terhadap nilai kualitas perangkat lunak pada pengembangan perangkat lunak berbasis Java. Tujuan utama penelitian adalah menentukan cara yang tepat dalam pemeriksaan kode untuk mencari smell code dan anti-pattern pada pengembangan perangkat lunak berbasis Java, serta melakukan evaluasi dampak penggunaan code inspection tools dan software metrics terhadap nilai kualitas perangkat lunak.

Memproduksi kode yang dirancang dengan baik selama tahap pengembangan memiliki nilai yang signifikan karena proses ini membuat proyek perangkat lunak lebih mudah dipahami dan menghasilkan kualitas kode yang lebih tinggi. Akibatnya, biaya pemeliharaan proyek perangkat lunak akan menurun [1].

Pengembangan perangkat lunak dengan menggunakan konsep Object Oriented Programming (OOP) dan tidak menggunakan kaidah bahasa pemrograman yang baik yang akan menghasilkan smell code serta penggunaan anti pattern dapat memberikan dampak sulitnya proses pemeliharaan [12]. Inspeksi terhadap kode pada tahap pembuatan program dinilai dapat meningkatkan nilai kualitas pada pengembangan perangkat lunak tersebut serta mengurangi biaya pemeliharaan. Penggunaan code inspection tools untuk inspeksi terhadap kode pada pengembangan perangkat lunak dinilai perlu untuk dievaluasi. Hal ini dikarenakan banyaknya pengembang akan berpartisipasi dalam pengembangan perangkat lunak yang diwariskan daripada mengerjakan proyek baru maka sangat penting untuk menciptakan proyek yang dapat dimengerti. Memperbaiki smell code atau menghindari anti pattern pada pembuatan perangkat lunak selama tahap pengembangan akan membuat aplikasi lebih mudah dipahami. Akibatnya, pengembang akan menghasilkan lebih banyak pekerjaan dalam waktu yang lebih singkat dan pendekatan ini akan mengurangi biaya pemeliharaan perangkat lunak [1].

Hal ini membuat code inspection tools yang akan digunakan pada pengembangan perangkat lunak perlu untuk dievaluasi kemampuan inspeksi terhadap kode untuk mendeteksi adanya smell code atau anti pattern untuk selanjutnya di-refactoring. Penggunaan code inspection tools dapat berpengaruh baik atau buruk terhadap cara memprogram pengembang untuk menyelesaikan persoalan yang hendak diselesaikannya [1]. 


\section{HIPOTESIS}

Hipotesis yang ingin dievaluasi, yaitu:

1. Smell code dan anti pattern dapat dideteksi dengan tepat oleh inspeksi terhadap kode menggunakan code inspection tools dan perhitungan software metrics.

2. Smell code dan anti pattern akan dapat ditemukan dengan tepat dengan cara inspeksi terhadap kode oleh code inspection tools dan perhitungan software metrics agar teknik refactoring yang dilakukan terhadap perangkat lunak akan menghasilkan kode dengan rancangan yang baik.

\section{Perangkat Lunak Pengukuran Metrik PEMROGRAMAN BERORIENTASI OBJEK}

Metrik pemrograman berorientasi objek adalah aspek yang harus dipertimbangkan. Metrik menjadi seperangkat standar yang dengannya seseorang dapat mengukur keefektifan teknik Analisis berorientasi objek dalam perancangan suatu sistem. Banyak metrik yang berbeda telah diusulkan untuk sistem berorientasi objek. Metrik berorientasi objek mengukur struktur prinsip yang, jika tidak dirancang dengan benar, berdampak negatif pada atribut kualitas desain dan kode. Metrik berorientasi objek yang ada terutama diterapkan pada konsep kelas, kopling, dan pewarisan [10].

\section{A. Weighted Methods per Class (WMC)}

WMC adalah penghitungan method yang diterapkan di dalam kelas atau jumlah kompleksitas method (kompleksitas method diukur dengan kompleksitas cyclomatic). Pengukuran kedua sulit dilaksanakan karena tidak semua method dapat dinilai dalam hierarki kelas karena warisan [10].

Definisi: Pertimbangkan Kelas $\mathrm{C} 1$, dengan methods M1...Mn yang didefinisikan di kelas. Biarkan c1...cn menjadi kompleksitas methods. Kemudian:

$$
\mathrm{WMC}=\sum_{i=1}^{n} c i
$$

Jika semua kompleksitas method dianggap kesatuan, maka $\mathrm{WMC}=\mathrm{n}$, jumlah method. Dasar teoritis: WMC berhubungan langsung dengan definisi kompleksitas Bunge tentang kompleksitas, karena method adalah sifat kelas objek dan kompleksitas ditentukan oleh kardinalitas rangkaian sifatnya. Oleh karena itu, jumlah method adalah ukuran definisi kelas dan juga atribut kelas, karena atribut sesuai dengan properti [13].

Sudut pandang: [10][13]

1. Jumlah method dan kompleksitas method yang terlibat adalah prediksi berapa banyak waktu dan usaha yang dibutuhkan untuk mengembangkan dan memelihara kelas.

2. Semakin besar jumlah method di kelas, semakin besar dampak potensial pada subkelas, karena subkelas akan mewarisi semua method yang didefinisikan di kelas.

3. Kelas dengan sejumlah besar method cenderung lebih spesifik aplikasi, sehingga membatasi kemungkinan penggunaan ulang.

\section{B. Depth of inheritance tree (DIT)}

Sudut kelas dengan hierarki warisan adalah jumlah langkah maksimum dari simpul kelas ke akar dan diukur dengan jumlah kelas leluhur. Metrik pendukung untuk DIT adalah jumlah method yang diwarisi (NMI) [10].

Definisi: Kedalaman pewarisan kelas adalah metrik DIT untuk kelas. Dalam kasus yang melibatkan multiple inheritance, DIT akan menjadi panjang maksimum dari node ke akar subkelas [13].

Dasar teoritis: DIT berhubungan dengan gagasan Bunge tentang ruang lingkup properti. DIT adalah ukuran berapa banyak kelas leluhur yang berpotensi mempengaruhi kelas ini [13].

Sudut pandang: [13][10]

1. Semakin dalam sebuah kelas berada dalam hirarki, semakin besar jumlah method yang cenderung diwarisi, membuatnya lebih kompleks untuk memprediksi perilakunya.

2. Subkelas yang lebih dalam merupakan kompleksitas desain yang lebih besar, karena lebih banyak method dan kelas terlibat.

3. Semakin dalam kelas tertentu berada dalam hirarki, semakin besar kemungkinan penggunaan kembali method warisan.

\section{Coupling Between Object Classes (CBO)}

Coupling Between Object Classes ( $\mathrm{CBO}$ ) adalah hitungan dari jumlah kelas lain dimana sebuah kelas digabungkan. Hal ini diukur dengan menghitung jumlah hierarki kelas non-inheritance yang berbeda dimana kelas bergantung. Kopling yang kuat mempersulit sistem karena kelas lebih sulit dipahami, diubah atau diperbaiki dengan sendirinya jika saling terkait dengan kelas lainnya. Merancang sistem dengan kopling terlemah di antara kelas dapat mengurangi kompleksitas. Hal ini meningkatkan modularitas dan meningkatkan enkapsulasi [10]. CBO untuk kelas adalah hitungan jumlah kelas lain yang digabungkan [13].

Dasar teoritis: [13] CBO berkaitan dengan gagasan bahwa suatu objek digabungkan ke objek lain jika salah satunya bertindak di sisi lain, yaitu method penggunaan atau variabel contoh lainnya. Seperti yang dinyatakan sebelumnya, karena objek dari kelas yang sama memiliki sifat yang sama, dua kelas digabungkan bila method dideklarasikan dalam satu method penggunaan kelas atau variabel contoh yang didefinisikan oleh kelas lainnya.

Sudut pandang: [10][13]

1. Kopling yang berlebihan antara kelas objek sangat merugikan desain modular dan mencegah penggunaan kembali. Kelas yang lebih independen 
adalah, semakin mudah untuk menggunakannya kembali di aplikasi lain.

2. Untuk meningkatkan modularitas dan meningkatkan enkapsulasi, pasangan kelas antar-objek harus dijaga seminimal mungkin. Semakin besar jumlah pasangan, semakin tinggi sensitivitas terhadap perubahan pada bagian desain lainnya, dan oleh karena itu perawatan lebih sulit.

3. Ukuran kopling berguna untuk menentukan seberapa rumit pengujian berbagai bagian dari suatu desain. Semakin tinggi kopling kelas antar objek, pengujian yang lebih ketat perlu dilakukan.

\section{Lack of Cohesion in Methods (LCOM)}

Lack of Cohesion (LCOM) mengukur ketidaksamaan method di kelas dengan variabel atau atribut. Modul yang sangat kohesif harus berdiri sendiri. Kohesi tinggi menunjukkan pembagian kelas yang baik. Kohesi tinggi menyiratkan kesederhanaan dan reusabilitas tinggi. (Cho, Kim, \& Kim, 2001)

Definisi: Pertimbangkan Kelas C1 dengan n methods M1, $\mathrm{M} 2 \ldots$, Mn. Misalkan $\{\mathrm{Ij}\}=$ set of instance variables yang digunakan dengan method Mi. Ada $\mathrm{n}$ set seperti $\{\mathrm{I} 1\}, \ldots$, $\{\mathrm{In}\}$. Misalkan $\mathrm{P}=\{(\mathrm{Ii}, \mathrm{Ij}) \mid \mathrm{Ii} \cap \mathrm{Ij}=\varnothing\}$ dan $\mathrm{Q}=\{(\mathrm{Ii}, \mathrm{Ij}) \mid \mathrm{Ii}$ $\left.\cap \mathrm{Ij}_{-} \varnothing\right\}$. (Chidamber \& Kemerer, 1994) $\varnothing$.

Jika semua $n$ set $\left\{\mathrm{I}_{1}\right\}, \ldots\{\mathrm{In}\}$ adalah $\varnothing$ lalu misalkan $\mathrm{P}=$

$$
\mathrm{LCOM}=|\mathrm{P}|-|\mathrm{Q}| \text {, if }|\mathrm{P}|>|\mathrm{Q}|
$$$$
=0 \text { otherwise } 28 \text {. }
$$

Dasar teoritis ini menggunakan konsep tingkat kemiripan method. Tingkat kesamaan untuk dua method M1 dan M2 pada kelas $\mathrm{C} 1$ diberikan oleh [13]. $\sigma()=\{\mathrm{I} 1\} \cap\{\mathrm{I} 2\}$ di mana $\{$ I1 $\}$ dan $\{$ I2 $\}$ adalah himpunan variabel contoh yang digunakan oleh M1 dan M2.

LCOM adalah penghitungan jumlah pasangan method yang kesamaannya adalah 0 (yaitu $\sigma()$ adalah himpunan nihil) dikurangi jumlah pasangan method yang kesamaannya tidak nol. Semakin besar jumlah method serupa, semakin kohesif kelas, yang konsisten dengan konsep tradisional tentang kohesi yang mengukur keterkaitan antara bagian program. Jika tidak ada method kelas yang menampilkan perilaku apa pun, yaitu tidak menggunakan variabel instan, mereka tidak memiliki kesamaan dan nilai LCOM untuk kelas akan menjadi nol [13].

Nilai LCOM memberikan ukuran sifat method yang relatif berbeda di kelas. Sejumlah kecil pasangan yang terputus-putus (unsur himpunan P) menyiratkan kesamaan method yang lebih besar. LCOM sangat terkait dengan variabel instance dan method kelas, dan oleh karena itu merupakan ukuran atribut dari kelas objek [13].

Sudut pandang: [13]

1. Kohesi method dalam kelas sangat diinginkan, karena mendorong enkapsulasi.

2. Kurangnya kohesi menyiratkan kelas mungkin harus dibagi menjadi dua atau lebih sub kelas.
3. Setiap ukuran ketidakteraturan method membantu mengidentifikasi kekurangan dalam desain kelas.

4. Kohesi rendah meningkatkan kompleksitas, sehingga meningkatkan kemungkinan kesalahan selama proses pembangunan.

\section{E. Cyclomatic Complexity (CC)}

Cyclomatic complexity adalah suatu software metric yang memberikan pengukuran logical complexity dari suatu program. Method ini menggunakan teori graph untuk menghitung kompleksitas program. Nilai kompleksitas dihitung dengan tiga cara, yaitu: [14][15]

1. Jumlah wilayah dari flow graph yang berhubungan dengan cyclomatic complexity.

2. Cyclomatic complexity $\mathrm{V}(\mathrm{G})$ didefiniskan dengan:

$$
\mathrm{V}(\mathrm{G})=\mathrm{E}-\mathrm{N}+2 \text {. }
$$

$\mathrm{E}$ adalah jumlah Edge, dan $\mathrm{N}$ adalah jumlah Node dalam flow graph.

3. Cyclomatic complexity $\mathrm{V}(\mathrm{G})$ juga didefinisikan dengan rumus:

$$
\mathrm{V}(\mathrm{G})=\mathrm{P}+1
$$

$P$ adalah jumlah predicated node pada flow graph $G$.

[16] mengatakan bahwa Myers mengusulkan metrik extended cyclomatic complexity $\mathrm{V}(\mathrm{G})$ turut memperhitungkan operator boolean (AND dan OR) dimasukkan dalam perhitungan nilai cyclomatic complexity.

\section{F. Lines of Code (LOC)}

Seperti namanya menunjukkan metrik LOC adalah ukuran modul dan ini mungkin merupakan metrik perangkat lunak tertua. Isu metrik LOC yang paling banyak dibahas adalah yang harus disertakan dalam ukuran [17] memeriksa empat aspek LOC yang harus dipertimbangkan, yaitu :garis kosong, baris komentar, deklarasi data, baris yang berisi beberapa instruksi terpisah.

Penggunaan praktis LOC dalam rekayasa perangkat lunak dapat diringkas sebagai berikut [18]:

1. Sebagai predikator pengembangan atau upaya pemeliharaan.

2. Sebagai kovarian untuk metrik lain, "menormalkan" mereka ke kepadatan kode yang sama.

Poin terpenting dari kedua penggunaan LOC ini, adalah fakta bahwa ia dapat digunakan sebagai penyesuaian kovarian untuk ukuran saat menggunakan metrik lainnya. Pertimbangkan dua kelas A dan B yang berbeda, di mana A memiliki nilai LOC jauh lebih tinggi daripada B. Jika seseorang ingin menghitung metrik WMC untuk kedua kelas, kemungkinan besar A mengembalikan nilai WMC tertinggi karena nilainya ukuran lebih besar Hasil ini terlalu bergantung pada ukuran kelas dan tidak memberikan representasi yang baik dari nilai WMC. Untuk memperbaiki ini, LOC dapat digunakan untuk menormalisasi kedua nilai WMC sehingga tidak bergantung pada ukuran tetapi hanya pada seberapa tinggi WMC yang dimiliki kedua kelas. 


\section{G. Source Line Of Code (SLOC)}

SLOC digunakan untuk menghitung estimasi banyaknya resource yang akan dialokasikan dalam pembuatan sebuah perangkat lunak. SLOC menjadi standar pengukuran pada metric yang berbasis size oriented [15]. Besarnya nilai SLOC dapat mempengaruhi nilai maintainability. SLOC didapatkan dengan cara menghitung jumlah kode baris pada suatu kode sumber. Komen atau spasi pada kode program tidak dihitung saat perhitungan [14].

Alasan pemilihan metrik NCLoC, halstead volume dan extended cyclomatic complexity dalam perhitungan nilai maintainability adalah agar terciptanya pengukuran kuantitatif. Pengukuran kuantitatif tersebut dilakukan dengan menghitung banyaknya variabel yang digunakan, banyaknya alur eksekusi dalam kode program, dan banyaknya baris kode program [14].

\section{H. Number of Parameters (NP)}

Metrik ini menghitung jumlah parameter dalam signature method untuk method atau konstruktor. Method dengan sejumlah besar parameter seringkali lebih sulit untuk digunakan kembali karena cenderung khusus dan ini menyiratkan bahwa kelas hilang dari model. Batas default untuk NP adalah 0 sampai dengan 4. Jika jumlah parameter melebihi 4, disarankan untuk memindahkan method yang dipanggil atau melewati sebuah objek. Secara umum, method dan konstruktor dengan lebih dari tiga parameter lebih sulit dipahami dan digunakan. Kode sumber dengan method yang memiliki daftar parameter panjang dan method invoking dengan signature serupa cenderung rawan kesalahan.

\section{Number of Attributes on Class (NOF)}

Total jumlah atribut dalam lingkup yang dipilih. Digunakan untuk menyusun bagaimana kompleks datanya. Cara menghitungnya yaitu hitung atribut yang terdapat di kelas. Pengembang cenderung berpikir bahwa kelas dengan jumlah atribut yang lebih tinggi mengandung informasi yang lebih kompleks: ini sangat salah! Misalnya kelas dengan 10 atribut integer lebih mudah dipahami daripada kelas dengan 4 linked list.

\section{J. Tight Class Cohesion (TCC)}

Definisi: Penentuan ukuran kohesi kelas ini berdasarkan pada koneksi langsung pasangan method. Misalkan NP (C) adalah jumlah total pasangan method abstrak di kelas C. Jika ada $\mathrm{n}$ method di kelas C, maka: [19]

$$
\mathrm{NP}(\mathrm{C})=(\mathrm{n} *(\mathrm{n}-1)) / 2 \text {. }
$$

Dua method terhubung secara langsung jika mereka mengakses variabel contoh umum. Biarkan NDC (C) menjadi jumlah koneksi langsung untuk kelas C. Metric Tight Class Cohesion (TCC) adalah jumlah relatif method yang terhubung secara langsung. Secara formal hal ini dapat dinyatakan sebagai: [19]

$$
\mathrm{TCC}(\mathrm{C})=(\mathrm{NDC}(\mathrm{C})) /(\mathrm{NP}(\mathrm{C}))
$$

Pengamatan: Nilai TCC dinormalisasi dalam kisaran antara $[0,1]$. Semakin tinggi nilai TCC untuk kelas, semakin kuat kohesi kelas tersebut, dan akibatnya semakin baik desainnya [19].

Kesimpulan: Kelas yang memiliki nilai TCC lebih rendah dari 0,5 (kadang-kadang 0,3) adalah kelas kandidat untuk proses perancangan ulang. Desain ulang terdiri dari kemungkinan pemisahan kelas dalam dua atau lebih kelas yang lebih kecil dan lebih kohesif. Dari perspektif lain subjek dengan TCC rendah mungkin menunjukkan kelas yang merangkum lebih dari satu fungsionalitas. Dengan kata lain, cacat desain yang dapat dideteksi dengan menggunakan TCC adalah kurangnya kohesi, dan satu cara konkret untuk mengurangi atau menghilangkannya mungkin merupakan pemecahan kelas [19].

\section{K. Access to Foreign Data (ATFD)}

Access to Foreign Data (ATFD) mewakili jumlah kelas eksternal dari mana kelas tertentu mengakses atribut, secara langsung atau melalui method aksesor. Method menggunakan secara langsung lebih dari beberapa atribut kelas lainnya [20].

\section{METODE PENELITIAN}

Penelitian dilakukan melalui tahapan mempelajari teori terkait kaidah bahas pemrograman Java yang baik, smell code, anti-pattern, object oriented programming, code inspection tools yang akan digunakan, refactoring, dan software metrics; melakukan pendefinisian dan klasifikasi properti dari smell code, anti-pattern, software metrics, dan teknik refactoring untuk dianalisis lebih lanjut pada kode program dengan melakukan kode inspeksi oleh code inspection tools dan dibandingkan dengan software metrics lalu dilakukan refactoring agar dapat membandingkan nilai dari kualitas kode program tersebut; melakukan analisis dan perancangan karakteristik pengembangan aplikasi Java dan penggunaan code inspection tools untuk pemeriksaan kode yang akan digunakan dalam penelitian; evaluasi terhadap sebuah studi kasus aplikasi berbasis Java sebagai sample untuk di inspeksi kode-nya untuk pendeteksian smell code dan anti pattern serta perhitungan software metrics.

Studi kasus aplikasi yang dipilih sebagai aplikasi sample adalah aplikasi E-Commerce dengan fungsionalitas pengelolaan data master barang dan customer serta pengelolaan data transaksi penjualan dan pembayaran. Tahapan evaluasi ini dimulai dari pengembangan aplikasi sample, inspeksi kode dengan code inspection tools serta menghitung software metrics setelah itu dilakukan analisis dan refactoring untuk selanjutnya di inspeksi kembali dan seterusnya hingga didapat pola aplikasi sesuai kaidah bahasa pemrograman berorientasi objek yang baik dan arsitektur pemrograman Java yang baik.

Metrik produk perangkat lunak mengukur produk perangkat lunak pada tahap pengembangan yang berbeda, mulai dari mengukur kompleksitas perancangan perangkat 
lunak hingga ukuran kode sumber akhir. Terukurnya smell code dan anti-pattern tergantung pada ukuran, kompleksitas, dan struktur smell code dan anti-pattern. beberapa smell code dan anti-pattern seperti "Long Method" dapat dengan mudah dideteksi oleh metrik perangkat lunak seperti kompleksitas Cyclomatic dan langkah-langkah Halstead. Beberapa smell code dan anti-pattern seperti "Dead Code" dan "Middle Man" sulit dideteksi oleh metrik perangkat lunak. Banyak smell code dan anti-pattern tampaknya tidak terdeteksi oleh metrik perangkat lunak. Properti refactoring menggambarkan solusi untuk setiap smell code dan antipattern. Beberapa refactoring bisa memecahkan beberapa smell code dan anti-pattern, dan beberapa smell code dan anti-pattern mungkin memerlukan beberapa metode refactoring untuk dihapus.

Untuk meningkatkan kualitas produk perangkat lunak, skenario terbaik adalah mengidentifikasi dan menghilangkan semua smell code dan anti-pattern dari kode sumber. Namun, pada kenyataannya, tidak semua code inspection tools dapat mengenali semua smell code dan antipattern. Misalnya, PMD dapat mengenali smell code Dead Code tetapi Checkstyle belum tentu dapat mengenali smell code Dead Code. Di sisi lain, tidak semua smell code dan anti-pattern memiliki tingkat kepentingan yang sama dengan kode sumbernya. Ada tradeoff antara biaya identifikasi / pemindahan smell code dan anti-pattern dan peningkatan kualitas perangkat lunak.

Kesimpulan ditarik dari hasil evaluasi studi kasus aplikasi Java dengan melihat nilai kualitas perangkat lunak dan membandingkan hasil code metrics pada saat aplikasi sebelum pengecekan kode dan sesudah refactoring kode program yang diminta setelah pengecekan kode.

Tabel I, II, III, IV, V dan VI berisikan definisi, cara mendeteksi dengan metrik perangkat lunak, cara melakukan refactoring dan code inspection tools yang dapat mendeteksi smell code dan anti pattern.

TABEL I

DEFINISI DARI SMELL CODE YANG AKAN DI EVALUASI

\begin{tabular}{|l|l|l|}
\hline No. & Smell Code & \multicolumn{1}{c|}{ Definisi } \\
\hline 1 & $\begin{array}{l}\text { Long } \\
\text { Parameter } \\
\text { List }\end{array}$ & $\begin{array}{l}\text { Terjadi saat penggabungan beberapa } \\
\text { algoritma dalam 1 metode, dimana } \\
\text { setiap algoritma butuh beberapa } \\
\text { parameter yang berbeda-beda. Berarti } \\
\text { sejumlah besar parameter dilanjutkan } \\
\text { menjadi satu konstruktor atau } \\
\text { statement dalam method yang } \\
\text { membuat kode tidak konstan. }\end{array}$ \\
\hline 2 & Large Class & $\begin{array}{l}\text { Kelas berisi banyak variabel, method } \\
\text { dan statement. Lebih banyak method, } \\
\text { variabel atau kondisi pengambilan } \\
\text { keputusan dalam satu kelas dapat } \\
\text { mengurangi kohesi. }\end{array}$ \\
\hline 3 & Lazy Class & $\begin{array}{l}\text { Kelas yang hanya memiliki sedikit } \\
\text { baris kode dan tidak memiliki } \\
\text { method. }\end{array}$ \\
\hline
\end{tabular}

\begin{tabular}{|l|c|l|}
\hline No. & Smell Code & \multicolumn{1}{c|}{ Definisi } \\
\hline 4 & Feature Envy & $\begin{array}{l}\text { Method mengakses objek data lain } \\
\text { lebih banyak dari pada datanya } \\
\text { sendiri. Menunjukkan method satu } \\
\text { kelas yang nampaknya lebih } \\
\text { ditujukan pada atribut kelas lain dari } \\
\text { kelasnya sendiri. }\end{array}$ \\
\hline 5 & Long Method & $\begin{array}{l}\text { Smell code ini menandakan jumlah } \\
\text { statement, variabel, kondisi } \\
\text { pengambilan keputusan dan kondisi } \\
\text { pengulangan yang banyak dalam satu } \\
\text { method yang menyebabkan method } \\
\text { terlalu panjang, sulit dimengerti dan } \\
\text { digunakan kembali. }\end{array}$ \\
\hline 6 & Dead Code & $\begin{array}{l}\text { Variabel, parameter, atribut, method } \\
\text { atau kelas tidak lagi digunakan } \\
\text { dikarena sudah usang. Kode semacam } \\
\text { itu juga dapat ditemukan dalam } \\
\text { kondisi kompleks, ketika salah satu } \\
\text { cabang tidak terjangkau karena } \\
\text { kesalahan atau keadaan lainnya. }\end{array}$ \\
\hline
\end{tabular}

TABEL II

KLASIFIKASI DARI SMELL CODE YANG AKAN DI EVALUASI

\begin{tabular}{|c|c|c|c|}
\hline No. & Smell Code & SW Metrics & Refactoring \\
\hline 1 & $\begin{array}{l}\text { Long } \\
\text { Parameter } \\
\text { List }\end{array}$ & NOP $>7$ & $\begin{array}{l}\text { *Preserve Whole } \\
\text { Object } \\
\text { *Replace } \\
\text { Parameter with } \\
\text { Method Object } \\
\text { *Introduce } \\
\text { Parameter } \\
\text { Object }\end{array}$ \\
\hline 2 & Large Class & $\begin{array}{l}\text { a. If LOC > 300 } \\
\& \text { long methods } \\
>5 \\
\text { b. If DIT > } 5 \\
\text { c. If CBO > } 10 \\
\text { *If there is } 1 \text { rule } \\
\text { above then this } \\
\text { smell code is } \\
\text { detected }\end{array}$ & $\begin{array}{l}\text { *Extract Class } \\
\text { *Extract SubClass } \\
\text { *Extract Interface } \\
\text { *Duplicate } \\
\text { Observed Data }\end{array}$ \\
\hline 3 & Lazy Class & $\begin{array}{l}\text { a. If NOM }=0 \\
\text { b. If LOC }<100 \\
\& \text { WMC }<=2 \\
\text { *If there is } 1 \text { rule } \\
\text { above then this } \\
\text { smell code is } \\
\text { detected }\end{array}$ & $\begin{array}{l}\text { *Collapse } \\
\text { Hierarchy } \\
\text { *Inline class }\end{array}$ \\
\hline 4 & $\begin{array}{l}\text { Feature } \\
\text { Envy }\end{array}$ & $\begin{array}{l}\text { a. If CBO > } 5 \\
\text { b. If LCOM > } 2 \\
\text { *If there is a rule } \\
\text { above then this } \\
\text { smell code is } \\
\text { detected }\end{array}$ & $\begin{array}{l}\text { *Move Method. } \\
\text { *Extract Method }\end{array}$ \\
\hline
\end{tabular}




\begin{tabular}{|c|c|c|c|}
\hline No. & Smell Code & SW Metrics & Refactoring \\
\hline 5 & $\begin{array}{l}\text { Long } \\
\text { Method }\end{array}$ & $\begin{array}{l}\text { a. } \mathrm{NOP}>7 \\
\text { b. } \mathrm{NLOC}>20 \\
\text { c. } \mathrm{VG}>5 \\
\text { d. } \mathrm{NBD}>6\end{array}$ & $\begin{array}{l}\text { *Extract Method } \\
\text { *Replace Temp } \\
\text { with Query } \\
\text { *Preserve Whole } \\
\text { Object } \\
\text { *Introduce } \\
\text { Parameter } \\
\text { Object } \\
\text { *Replace Method } \\
\text { with Method } \\
\text { Object } \\
\text { *Extract Method } \\
\text { *Decompose } \\
\text { Conditional }\end{array}$ \\
\hline 6 & Dead Code & - & $\begin{array}{l}\text { *Collapse } \\
\text { Hierarchy } \\
\text { *Inline Class } \\
\text { *Rename Method } \\
\text { *Remove } \\
\text { Parameter } \\
\text { *Subtitute } \\
\text { Algorithm }\end{array}$ \\
\hline
\end{tabular}

TABEL III

TOOLS DARI SMELL CODE YANG AKAN DI EVALUASI

\begin{tabular}{|l|l|l|}
\hline No. & \multicolumn{1}{|c|}{ Smell Code } & \multicolumn{1}{c|}{ Tools } \\
\hline 1 & Long Parameter List & Checkstyle \\
\hline 2 & Large Class & Tidak ada \\
\hline 3 & Lazy Class & Tidak ada \\
\hline 4 & Feature Envy & JDeodorant \\
\hline 5 & Long Method & JDeodorant \\
\hline 6 & Dead Code & $\begin{array}{l}\text { Dead Code Detector, PMD, } \\
\text { Elimination by IDE }\end{array}$ \\
\hline
\end{tabular}

TABEL IV

DEFINISI DARI ANTI PATTERN YANG AKAN DI EVALUASI

\begin{tabular}{|l|l|l|}
\hline No. & \multicolumn{1}{|c|}{$\begin{array}{c}\text { Anti } \\
\text { Pattern }\end{array}$} & \multicolumn{1}{c|}{ Definisi } \\
\hline 1 & $\begin{array}{l}\text { The Blob / } \\
\text { God Class }\end{array}$ & $\begin{array}{l}\text { Kelas tunggal yang memiliki banyak } \\
\text { atribut dan method yang tidak terkait } \\
\text { yang tercakup dalam satu kelas. } \\
\text { Kurangnya arsitektur berorientasi objek } \\
\text { dan terlalu terbatas intervensi. }\end{array}$ \\
\hline 2 & Lava Flow & $\begin{array}{l}\text { Method, kelas, atau atribut yang tidak } \\
\text { terdokumentasi dan tidak jelas } \\
\text { berhubungan dengan arsitektur sistem. } \\
\text { Terdapat kode yang tidak terpakai atau } \\
\text { usang. Seiring arus dan waktu, dengan } \\
\text { cepat menjadi tidak mungkin untuk } \\
\text { mendokumentasikan kode atau } \\
\text { memahami arsitekturnya cukup untuk } \\
\text { melakukan perbaikan. }\end{array}$ \\
\hline
\end{tabular}

TABEL V

KLASIFIKASI DARI ANTI PATTERN YANG AKAN DI EVALUASI

\begin{tabular}{|l|l|l|l|}
\hline No. & Anti Pattern & \multicolumn{1}{|c|}{ SW Metrics } & \multicolumn{1}{c|}{ Refactoring } \\
\hline 1 & $\begin{array}{l}\text { The Blob / } \\
\text { God Class }\end{array}$ & $\begin{array}{l}\text { a. WMC }>47 \\
\text { b. NOF }>60 \\
\text { c. ATFD }>5 \\
\text { d. TCC }>0.33\end{array}$ & $\begin{array}{l}\text { *Extract Class } \\
* \text { MVC Design Pattern }\end{array}$ \\
\hline 2 & Lava Flow & - & $\begin{array}{l}\text { *Collapse Hierarchy } \\
\text { *Inline Class } \\
\text { *Rename Method } \\
\text { *Remove Parameter } \\
\text { *Subtitute Algorithm }\end{array}$ \\
\hline
\end{tabular}

TABEL VI

TOOLS DARI ANTI PATTERN YANG AKAN DI EVALUASI

\begin{tabular}{|l|l|l|}
\hline No. & Anti Pattern & \multicolumn{1}{c|}{ Tools } \\
\hline 1 & $\begin{array}{l}\text { The Blob / } \\
\text { God Class }\end{array}$ & PMD \\
\hline 2 & Lava Flow & $\begin{array}{l}\text { Dead Code Detector, PMD, Elimination by } \\
\text { IDE }\end{array}$ \\
\hline
\end{tabular}

\section{Properti SMELL CODE, ANTI PATTERN, CODE INSPECTION TOOLS DAN SOFTWARE METRICS}

Banyak sifat anti pattern yang ada ditentukan oleh Brown, dkk [21]. Dalam penelitian ini properti yang dipilih adalah nama, penyebab, konsekuensi, gejala, dan refactoring. Properti lain seperti akar penyebab, variasi, latar belakang, dan bentuk umum tidak disertakan karena bergantung pada pengalaman pribadi pengembang perangkat lunak [21]. Properti smell code yang dipilih adalah nama, gejala, metrik, dan solusi atau refactoring. Gejala properti menggambarkan bagaimana menemukan smell code.

Mendefinisikan properti refactoring sebagai nama, skenario, dan mekanika. Nama refactoring biasanya terdiri dari operasi dan objek. Misalnya, untuk refactoring "Remove Middle Man", "Remove" adalah operasi sementara "Middle Man" adalah sebuah objek. Properti skenario memberikan deskripsi untuk setiap refactoring tentang kapan akan diterapkan. Properti mekanik menjelaskan bagaimana menerapkan metode langkah demi langkah untuk setiap refactoring untuk memecahkan masalah terkait. Penelitian ini berfokus pada refactoring yang dibutuhkan [7].

Metode pengujian tradisional tidak dapat secara efektif mengidentifikasi smell code atau anti pattern. Dan praktik review membaca baris demi baris untuk memverifikasi kualitas, kinerja, ukuran, dan produktivitas tidak efektif dalam hal waktu dan biaya. Proses ini membutuhkan waktu dari proses bisnis yang penting, memperlambat proses pengembangan dan menyebabkan cacat yang mampu menghasilkan masalah sistem secara keseluruhan di beberapa lapisan aplikasi. Cacat yang tidak diketahui termasuk beberapa lapisan aplikasi yang menyebabkan malapetaka dalam infrastruktur. Masalah yang tidak terdeteksi ini rata-rata $52 \%$ dari upaya yang diperlukan untuk memperbaiki masalah sistem [22]. Saat ini ada 
sejumlah besar alat yang tersedia, yang secara otomatis memeriksa kode pengembang dan menyarankan perubahan pada kode untuk pemeliharaan atau kebenaran. Alat analisis kode statis bertujuan menyoroti kemungkinan kesalahan sebagai peringatan, yang dapat diperiksa oleh pengembang. Jika peringatan itu mungkin dan alat ini mampu melakukannya, maka bisa langsung memperbaikinya, jika diinginkan oleh pengguna [23].

Smell code dan anti pattern bisa dideteksi secara heuristik tergantung dari pengalaman seorang programmer atau melalui aplikasi metrik perangkat lunak [13][18]. Metrik properti adalah bagaimana metrik perangkat lunak digunakan untuk mengidentifikasi smell code dan anti pattern.

\section{EVAluasi PENGGUNAAN CODE INSPECTION TOOLS DAN SOFTWARE METRICS PADA PENGEMBANGAN PERANGKAT LUNAK}

Evaluasi dilakukan dengan mendapatkan hasil kode inspeksi dan nilai perhitungan metrik yang dibutuhkan berdasarkan pencarian smell code dan anti pattern, setelah itu dilakukan refactoring untuk menghilangkan smell code dan anti pattern. Netbeans IDE digunakan untuk proses pembuatan studi kasus. Selain itu, IDE Netbeans ditambahkan dengan plugin Checstyle and Dead Code Detector untuk pemeriksaan kode dan Source Code Metrics untuk menghitung metrik perangkat lunak, yaitu WMC, TCC, NOM, NOF, LCOM, NOP, LOC, VG, dan NBD. Selain IDE Netbeans, IDE Eclipse juga ditambahkan dengan plugin PMD dan JDeodorant untuk pemeriksaan kode. Checkstyle dapat mendeteksi Long Parameter Lists, Dead Code Detector dapat mendeteksi Dead Code / Lava Flow, PMD dapat mendeteksi God Class, dan JDeodorant dapat mendeteksi God Class, Long Method, dan Feature Envy. Selain menghitung metrik perangkat lunak yang digunakan juga CKJM (Chidamber dan Kemerer Java Metrics) untuk menghitung metrik perangkat lunak DIT dan CBO. Deteksi kode dalam studi kasus dilakukan secara bertahap mulai dari PMD, JDeodorant, Checkstyle, dan Dead Code Detector terakhir.

Pola desain $(\mathrm{MC}) \mathrm{V}$, lapisan model dan conttoller disatukan. Tujuan penggunaan pola (MC)V adalah menjaga lapisan back-end dan front-end pada studi kasus. Package model berisikan objek data dan operasi untuk pengelolaan objek data tersebut dan package view yang terpisah serta dibangun dengan God Class dan Large Class untuk menerapkan smell code dan anti pattern.

Evaluasi dan refactoring dilakukan bertahap pada studi kasus, dimulai dari inspeksi kode oleh code inspection tools dan perhitungan software metrics lalu dianalisis dan dilakukan perbaikan kode dengan teknik refactoring agar sesuai dengan kaidah bahasa pemrograman berorientasi objek yang baik hingga kode tidak terdeteksi smell code dan anti pattern dari kode baseline. Tabel VII adalah jenis code inspection dan jenis dari evaluasi yang dilakukan.
TABEL VII

REFERENSI NOMOR, CODE INSPECTION, JENIS HASIL INSPEKSI KODE DAN Perhitungan Software Metric Sub Bab A-E

\begin{tabular}{|l|l|l|}
\hline No & \multicolumn{1}{|c|}{ Code Inspection } & \multicolumn{1}{|c|}{ Jenis } \\
\hline 1 & The Blob / God Class & Anti-Pattern \\
\hline 2 & Lava Flow & Anti-Pattern \\
\hline 3 & Long Parameter List & Smell Code \\
\hline 4 & Large Class & Smell Code \\
\hline 5 & Lazy Class & Smell Code \\
\hline 6 & Feature Envy & Smell Code \\
\hline 7 & Long Method & Smell Code \\
\hline 8 & Dead Code & Smell Code \\
\hline
\end{tabular}

A. Hasil Inspeksi Kode dan Perhitungan Software Metric pada Code Baseline

Gambar 1. Class Diagram Kode Sumber Baseline terdapat menggambarkan dua kelas yakni Barang dan JualDetail yang terdapat pada paket model yang berfungsi sebagai model data dan logika proses bisnis aplikasi serta satu kelas ECommerceBean yang terdapat pada paket bean yang berfungsi sebagai ManageBean yaitu kelas yang mengelola passing data ke XHTML dan pengelola alur data ke Entity Java Bean (EJB).

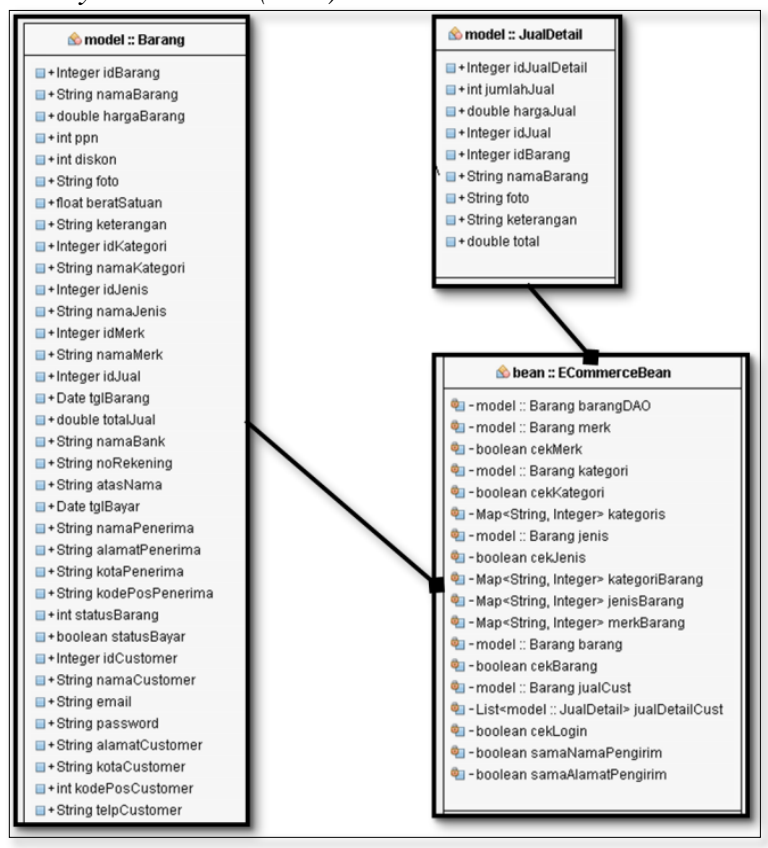

Gambar 1. Class Diagram Kode Sumber Baseline 
TABEL VIII

HASIL INSPEKSI KODE PADA SUMBER KODE BASELINE E-COMMERCE

\begin{tabular}{|c|c|c|}
\hline \multirow{2}{*}{ No } & \multicolumn{2}{|c|}{ Code Inspection Tools } \\
\hline & Tools & Hasil \\
\hline \multirow[t]{2}{*}{1} & PMD & $\begin{array}{l}\text { Kelas ECommerceBean dan } \\
\text { Barang terdeteksi God Class }\end{array}$ \\
\hline & JDeodorant & $\begin{array}{l}\text { Kelas ECommerceBean dan } \\
\text { Barang terdeteksi God Class } \\
\text { dengan refactoring Extract } \\
\text { Class }\end{array}$ \\
\hline 2 & $\begin{array}{l}\text { Dead Code Detector, } \\
\text { PMD, Elimination by } \\
\text { IDE }\end{array}$ & Tidak terdeteksi \\
\hline 3 & Checkstyle & $\begin{array}{l}\text { Kelas Barang terdeteksi Long } \\
\text { Parameter List }\end{array}$ \\
\hline 4 & - & Tidak terdeteksi \\
\hline 5 & - & Tidak terdeteksi \\
\hline 6 & JDeodorant & $\begin{array}{l}\text { Kelas ECommerceBean terdeteksi } \\
\text { Feature Envy dan Refactoring } \\
\text { Move Method }\end{array}$ \\
\hline 7 & JDeodorant & $\begin{array}{l}\text { Kelas ECommerceBean dan } \\
\quad \text { Barang terdeteksi Long Method }\end{array}$ \\
\hline 8 & $\begin{array}{l}\text { Dead Code Detector, } \\
\text { PMD, Elimination by } \\
\text { IDE }\end{array}$ & Tidak terdeteksi \\
\hline
\end{tabular}

TABEL IX

Hasil Perhitungan SoftWare Metric PADA SUMBer Kode Baseline ECOMMERCE

\begin{tabular}{|c|c|c|}
\hline \multirow{2}{*}{ No } & \multicolumn{2}{|c|}{ Software Metrics } \\
\hline & Nilai Deteksi & Nilai Hasil Pengukuran \\
\hline 1 & $\begin{array}{l}\mathrm{WMC}>47 \\
\text { NOF }>15 \\
\text { ATFD }>5 \\
\text { TCC }<0.33\end{array}$ & $\begin{array}{l}\text { ECommerceBean: terdeteksi } \\
\text { God Class } \\
\text { a. } \mathrm{WMC}=60 \\
\text { b. } \mathrm{NOF}=18 \\
\text { c. } \mathrm{ATFD}=66 \\
\text { d. } \mathrm{TCC}=0.15078901 \\
\text { Barang: terdeteksi God Class } \\
\text { a. } \mathrm{WMC}=109 \\
\text { b. } \mathrm{NOF}=35 \\
\text { c. } \mathrm{ATFD}=241 \\
\text { d. } \text { TCC }=0.07504004\end{array}$ \\
\hline 2 & - & Tidak terdeteksi \\
\hline 3 & NOP $>7$ & $\begin{array}{l}\text { Kelas Barang terdeteksi Long } \\
\text { Parameter List }\end{array}$ \\
\hline 4 & $\begin{array}{l}\text { a. } \mathrm{LOC}>300 \& \text { long } \\
\text { methods }>5 . \\
\text { b. } \text { DIT }>5 \\
\text { c. } \mathrm{CBO}>10\end{array}$ & $\begin{array}{l}\text { Kelas Barang terdeteksi Large } \\
\text { Class }\end{array}$ \\
\hline 5 & $\begin{array}{l}\text { a. } \mathrm{NOM}=0 \\
\text { b. LOC }<100 \& \text { WMC } \\
<=2\end{array}$ & $\begin{array}{l}\text { Kelas JualDetail terdeteksi Lazy } \\
\quad \text { Class }\end{array}$ \\
\hline 6 & $\begin{array}{l}\mathrm{CBO}>5 \\
\mathrm{LCOM}>2\end{array}$ & Tidak terdeteksi \\
\hline
\end{tabular}

\begin{tabular}{|r|l|l|}
\hline \multirow{2}{*}{ No } & \multicolumn{2}{|c|}{ Software Metrics } \\
\cline { 2 - 3 } & \multicolumn{1}{|c|}{ Nilai Deteksi } & Nilai Hasil Pengukuran \\
\hline 7 & NOP $>7$ & Tidak terdeteksi \\
& NLOC $>20$ & \\
& VG $>5$ & \\
& NBD $>6$ & Tidak terdeteksi \\
\hline 8 & - & \\
\hline
\end{tabular}

Tabel VIII dan IX menampilkan hasil dari inspeksi kode dan perhitungan software metric yang didapat dari kode sumber hasil Gambar 1. Class Diagram Kode Sumber Baseline. Hasil dari Tabel VIII dan IX dirangkun dalam Tabel X dengan menandakan terdeteksi atau tidak terdeteksi suatu code inspection pada sumber kode kelas yang dibuat.

TABEL X

HASIL DARI SuMBER KODE BASELINE E-COMMERCE

\begin{tabular}{|c|c|c|c|c|c|}
\hline No & Jenis & ECB & B & JD & Hasil Deteksi \\
\hline \multirow{2}{*}{1} & $\mathrm{~T}$ & 1 & 1 & 0 & 2 \\
\hline & SW & 1 & 1 & 0 & 2 \\
\hline \multirow{2}{*}{2} & $\mathrm{~T}$ & 0 & 0 & 0 & 0 \\
\hline & SW & 0 & 0 & 0 & 0 \\
\hline \multirow{2}{*}{3} & $\mathrm{~T}$ & 0 & 1 & 0 & 1 \\
\hline & SW & 0 & 1 & 0 & 1 \\
\hline \multirow{2}{*}{4} & $\mathrm{~T}$ & 0 & 0 & 0 & 0 \\
\hline & SW & 0 & 1 & 0 & 1 \\
\hline \multirow{2}{*}{5} & $\mathrm{~T}$ & 0 & 0 & 0 & 0 \\
\hline & SW & 0 & 0 & 1 & 1 \\
\hline \multirow{2}{*}{6} & $\mathrm{~T}$ & 1 & 0 & 0 & 1 \\
\hline & SW & 0 & 0 & 0 & 0 \\
\hline \multirow{2}{*}{7} & $\mathrm{~T}$ & 1 & 1 & 0 & 2 \\
\hline & SW & 0 & 0 & 0 & 0 \\
\hline \multirow{2}{*}{8} & $\mathrm{~T}$ & 0 & 0 & 0 & 0 \\
\hline & SW & 0 & 0 & 0 & 0 \\
\hline & & \multicolumn{3}{|c|}{ Total } & 11 \\
\hline & & \multicolumn{3}{|c|}{ Rata-Rata } & 0.229166667 \\
\hline
\end{tabular}

Keterangan:

1: Terdeteksi

0 : Tidak Terdeteksi

T: Tools

SW: Software Metric

ECB: kelas ECommerceBean

B: kelas Barang

JD: kelas JualDetail 


\section{B. Hasil Inspeksi Kode dan Perhitungan Software Metric} pada Code Versi - 1

Gambar 2. Class Diagram Kode Versi-1 ini menggambarkan hasil Extract Class untuk menanggulangi God Class dan Replace Parameter with Method Object untuk menanggulangi Long Parameter Lists pada code baseline bagian paket model. Dari Extract Class ini menjadi tujuh buah kelas yang terdapat pada paket model yang berfungsi sebagai model data dan logika proses bisnis aplikasi dan satu kelas ECommerceBean yang terdapat pada paket bean yang berfungsi sebagai kelas yang mengelola passing data ke XHTML dan pengelola alur data ke EJB.

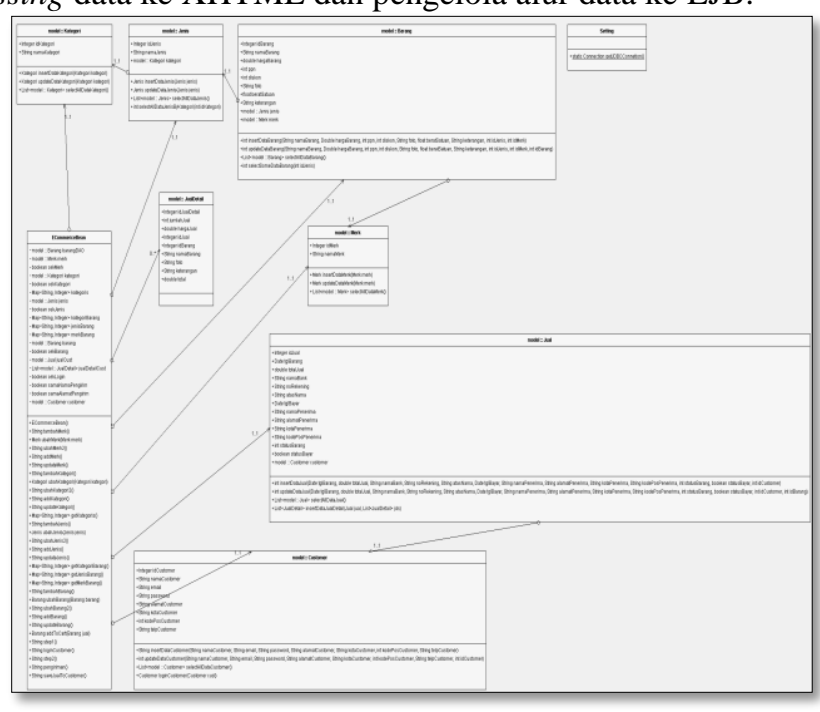

Gambar 2. Class Diagram Kode Versi-1

TABEL XI

HASIL INSPKESI KOdE PADA SUMBER KODE VERSI-1 E-COMMERCE

\begin{tabular}{|c|c|c|}
\hline \multirow{2}{*}{ No } & \multicolumn{2}{|c|}{ Code Inspection Tools } \\
\hline & Tools & Hasil \\
\hline \multirow[t]{2}{*}{1} & PMD & $\begin{array}{l}\text { Kelas ECommerceBean terdeteksi } \\
\text { God Class }\end{array}$ \\
\hline & JDeodorant & $\begin{array}{l}\text { Kelas ECommerceBean terdeteksi } \\
\text { God Class dengan refactoring } \\
\text { Extract Class; }\end{array}$ \\
\hline 2 & $\begin{array}{l}\text { Dead Code Detector, } \\
\text { PMD, Elimination by } \\
\text { IDE }\end{array}$ & Tidak terdeteksi \\
\hline 3 & Checkstyle & $\begin{array}{l}\text { 1. Kelas Barang, Customer, Jual } \\
\text { terdeteksi Long Parameter List }\end{array}$ \\
\hline 4 & - & Tidak terdeteksi \\
\hline 5 & - & Tidak terdeteksi \\
\hline 6 & JDeodorant & $\begin{array}{l}\text { Kelas ECommerceBean terdeteksi } \\
\text { Feature Envy dan Refactoring } \\
\text { Move Method }\end{array}$ \\
\hline 7 & JDeodorant & $\begin{array}{l}\text { Kelas ECommerceBean dan } \\
\text { Barang terdeteksi Long Method }\end{array}$ \\
\hline 8 & $\begin{array}{l}\text { Dead Code Detector, } \\
\text { PMD, Elimination by } \\
\text { IDE }\end{array}$ & Tidak terdeteksi \\
\hline
\end{tabular}

TABEL XII

Hasil Perhitungan SoftWare METRIC PADA Sumber Kode Versi- 1 ECOMMERCE

\begin{tabular}{|c|l|l|}
\hline \multirow{2}{*}{ No } & \multicolumn{2}{|c|}{ Software Metrics } \\
\cline { 2 - 3 } & \multicolumn{1}{|c|}{ Nilai Deteksi } & \multicolumn{1}{c|}{ Nilai Hasil Pengukuran } \\
\hline 1 & $\begin{array}{l}\text { WMC }>47 \\
\text { NOF }>15 \\
\text { ATFD }>5 \\
\text { TCC }<0.33\end{array}$ & $\begin{array}{l}\text { Kelas ECommerceBean: } \\
\text { terdeteksi God Class } \\
\text { a. WMC }=60 \\
\text { b. NOF }=19 \\
\text { c. ATFD }=66 \\
\text { d. TCC }=0.1\end{array}$ \\
\hline 2 & - & Tidak terdeteksi \\
\hline 3 & $\begin{array}{l}\text { NOP }>7 \\
\text { Kelas Barang, Customer, } \\
\text { Jual terdeteksi Long } \\
\text { Parameter List }\end{array}$ \\
\hline 4 & $\begin{array}{l}\text { LOC }>300 \& \text { long } \\
\text { methods }>5 \\
\text { DIT }>5 \\
\text { CBO }>10\end{array}$ & $\begin{array}{l}\text { Tidak terdeteksi } \\
\text { NOM }=0 \\
\text { LOC }<100 \& \text { WMC } \\
<=2\end{array}$ \\
\hline 6 & $\begin{array}{l}\text { CBO }>5 \\
\text { LCOM }>2\end{array}$ & $\begin{array}{l}\text { Kelas JualDetail terdeteksi } \\
\text { Lazy Class }\end{array}$ \\
\hline 7 & $\begin{array}{l}\text { NOP }>7 \\
\text { NLOC }>20 \\
\text { VG }>5 \\
\text { NBD }>6\end{array}$ & Tidak terdeteksi \\
\hline 8 & - & Tidak terdeteksi \\
\hline
\end{tabular}

Tabel XI dan XII menampilkan hasil dari inspeksi kode dan perhitungan software metric yang didapat dari kode sumber hasil Gambar 2. Class Diagram Kode Versi-1. Hasil dari Tabel XI dan XII dirangkun dalam Tabel XIII dengan menandakan terdeteksi atau tidak terdeteksi suatu code inspection pada sumber kode kelas yang dibuat.

TABEL XIII

HASIL DARI SUMBER KODE VERSI-1 E-COMMERCE

\begin{tabular}{|c|c|c|c|c|c|c|c|c|c|c|c|}
\hline No & Jns & $\begin{array}{c}\text { EC } \\
\text { B }\end{array}$ & $\mathbf{K}$ & $\mathbf{J}$ & $\mathbf{M}$ & B & C & $\mathbf{J l}$ & JD & $\mathbf{S}$ & $\begin{array}{c}\text { Hasil } \\
\text { Detek } \\
\text { si }\end{array}$ \\
\hline \multirow{2}{*}{1} & $\mathrm{~T}$ & 1 & 0 & 0 & 0 & 0 & 0 & 0 & 0 & 0 & 1 \\
\hline & SW & 1 & 0 & 0 & 0 & 0 & 0 & 0 & 0 & 0 & 1 \\
\hline \multirow{2}{*}{2} & $\mathrm{~T}$ & 0 & 0 & 0 & 0 & 0 & 0 & 0 & 0 & 0 & 0 \\
\hline & SW & 0 & 0 & 0 & 0 & 0 & 0 & 0 & 0 & 0 & 0 \\
\hline \multirow{2}{*}{3} & $\mathrm{~T}$ & 0 & 0 & 0 & 0 & 1 & 1 & 1 & 0 & 0 & 3 \\
\hline & SW & 0 & 0 & 0 & 0 & 1 & 1 & 1 & 0 & 0 & 3 \\
\hline \multirow{2}{*}{4} & $\mathrm{~T}$ & 0 & 0 & 0 & 0 & 0 & 0 & 0 & 0 & 0 & 0 \\
\hline & SW & 0 & 0 & 0 & 0 & 0 & 0 & 0 & 0 & 0 & 0 \\
\hline \multirow{2}{*}{5} & $\mathrm{~T}$ & 0 & 0 & 0 & 0 & 0 & 0 & 0 & 0 & 0 & 0 \\
\hline & SW & 0 & 0 & 0 & 0 & 0 & 0 & 0 & 1 & 0 & 1 \\
\hline 6 & $\mathrm{~T}$ & 1 & 0 & 0 & 0 & 0 & 0 & 0 & 0 & 0 & 1 \\
\hline
\end{tabular}




\begin{tabular}{|c|c|c|c|c|c|c|c|c|c|c|c|}
\hline \multirow[t]{2}{*}{ No } & Jns & $\begin{array}{c}\text { EC } \\
\text { B }\end{array}$ & $\mathbf{K}$ & $\mathbf{J}$ & $\mathbf{M}$ & B & C & $\mathbf{J l}$ & JD & $\mathbf{S}$ & $\begin{array}{c}\text { Hasil } \\
\text { Detek } \\
\text { si }\end{array}$ \\
\hline & SW & 0 & 0 & 0 & 0 & 0 & 0 & 0 & 0 & 0 & 0 \\
\hline \multirow{2}{*}{7} & $\mathrm{~T}$ & 1 & 0 & 0 & 0 & 1 & 0 & 0 & 0 & 0 & 2 \\
\hline & SW & 0 & 0 & 0 & 0 & 0 & 0 & 0 & 0 & 0 & 0 \\
\hline \multirow{2}{*}{8} & $\mathrm{~T}$ & 0 & 0 & 0 & 0 & 0 & 0 & 0 & 0 & 0 & 0 \\
\hline & SW & 0 & 0 & 0 & 0 & 0 & 0 & 0 & 0 & 0 & 0 \\
\hline & & & & & & & \multicolumn{4}{|c|}{ Total } & 12 \\
\hline & & & & & & & \multicolumn{4}{|c|}{ Rata-Rata } & $\begin{array}{r}0.083 \\
33333 \\
3\end{array}$ \\
\hline
\end{tabular}

\begin{tabular}{|l|l|}
\hline Keterangan: & Keterangan: \\
1: Terdeteksi & M: kelas Merk \\
0: Tidak Terdeteksi & B: kelas Barang \\
T: Tools & C: kelas Customer \\
SW: Software Metric & Jl: kelas Jual \\
ECB: kelas ECommerceBean & JD: kelas JualDetail \\
K: kelas Kategori & S: kelas Setting \\
J: kelas Jenis & \\
\hline
\end{tabular}

\section{Hasil Inspeksi Kode dan Perhitungan Software Metric} pada Code Versi - 2

Gambar 3. Class Diagram Kode Versi-2 ini menggambarkan hasil penerapan framework Java Persistence API (JPA) untuk pengelolaan antara Java dan basis data serta untuk refactoring Long Method pada kelas controller. Dari refactoring ini terdapat dua kelas controller yang terdapat pada paket control yang berfungsi sebagai kelas yang mengelola passing data ke XHTML dan pengelola alur data ke EJB.

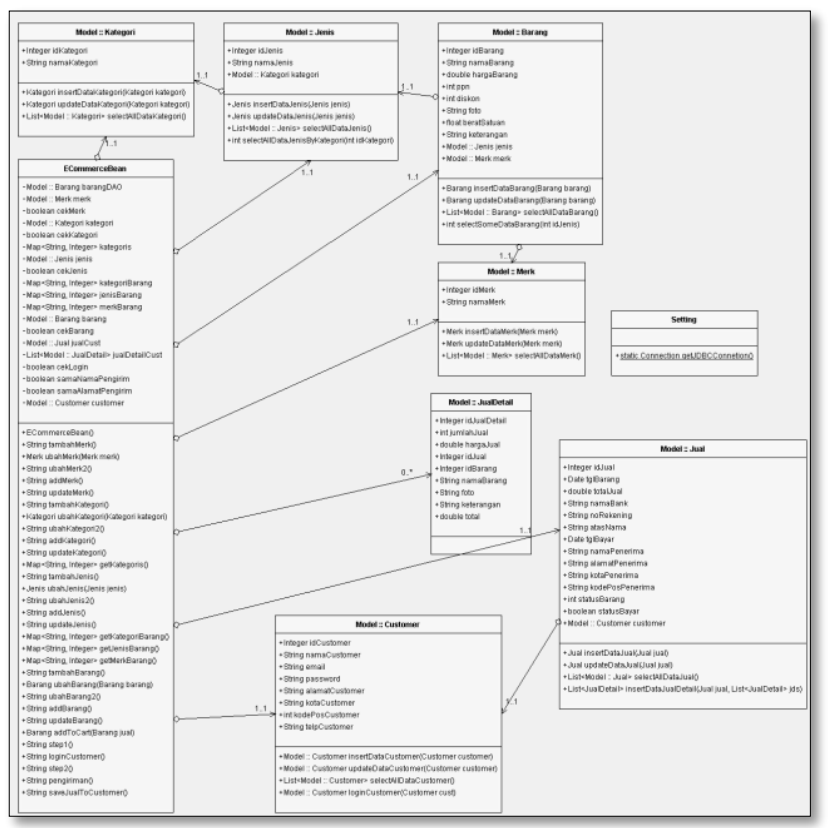

Gambar 3. Class Diagram Kode Versi-2
TABEL XIV

HASIL INSPKESI KODE PADA SUMBER KODE VERSI-2 E-COMMERCE

\begin{tabular}{|c|c|c|}
\hline \multirow{2}{*}{ No } & \multicolumn{2}{|c|}{ Code Inspection Tools } \\
\hline & Nama Tools & Hasil \\
\hline \multirow[t]{2}{*}{1} & PMD & $\begin{array}{l}\text { Kelas ECommerceBean } \\
\text { terdeteksi God Class }\end{array}$ \\
\hline & JDeodorant & $\begin{array}{l}\text { Kelas ECommerceBean } \\
\text { terdeteksi God Class dengan } \\
\text { refactoring Extract Class; }\end{array}$ \\
\hline 2 & $\begin{array}{l}\text { Dead Code Detector, } \\
\text { PMD, Elimination by } \\
\text { IDE }\end{array}$ & Tidak terdeteksi \\
\hline 3 & Checkstyle & Tidak terdeteksi \\
\hline 4 & - & Tidak terdeteksi \\
\hline 5 & - & Tidak terdeteksi \\
\hline 6 & JDeodorant & $\begin{array}{l}\text { Kelas ECommerceBean } \\
\text { terdeteksi Feature Envy dan } \\
\text { Refactoring Move Method; }\end{array}$ \\
\hline 7 & JDeodorant & $\begin{array}{l}\text { Kelas ECommerceBean dan } \\
\text { Barang terdeteksi Long } \\
\text { Method }\end{array}$ \\
\hline 8 & $\begin{array}{l}\text { Dead Code Detector, } \\
\text { PMD, Elimination by } \\
\text { IDE }\end{array}$ & Tidak terdeteksi \\
\hline
\end{tabular}

TABEL XV

Hasil Perhitungan SoftWARE METRIC PADA Sumber Kode VERSI-2 ECOMMERCE

\begin{tabular}{|c|c|c|}
\hline \multirow{2}{*}{ No } & \multicolumn{2}{|c|}{ Software Metrics } \\
\hline & Nilai Deteksi & Nilai Hasil Pengukuran \\
\hline 1 & $\begin{array}{l}\text { WMC }>47 \\
\text { NOF }>15 \\
\text { ATFD }>5 \\
\text { TCC }<0.33\end{array}$ & $\begin{array}{l}\text { Kelas ECommerceBean: } \\
\text { terdeteksi God Class } \\
\text { a. WMC }=60 \\
\text { b. } \text { NOF }=19 \\
\text { c. } \text { ATFD }=66 \\
\text { d. } \text { TCC }=0.1\end{array}$ \\
\hline 2 & - & Tidak terdeteksi \\
\hline 3 & $\mathrm{NOP}>7$ & Tidak terdeteksi \\
\hline 4 & $\begin{array}{l}\text { LOC }>300 \& \text { long } \\
\text { methods }>5 \\
\text { DIT }>5 \\
\mathrm{CBO}>10\end{array}$ & Tidak terdeteksi \\
\hline 5 & $\begin{array}{l}\mathrm{NOM}=0 \\
\mathrm{LOC}<100 \& \\
\mathrm{WMC}<=2\end{array}$ & $\begin{array}{l}\text { Kelas JualDetail: terdeteksi } \\
\text { Lazy Class } \\
\text { NOM }=0 \\
\text { LOC }=19 \& \text { WMC }=0\end{array}$ \\
\hline 6 & $\begin{array}{l}\text { CBO > } 5 \\
\text { LCOM > } 2\end{array}$ & Tidak terdeteksi \\
\hline 7 & $\begin{array}{l}\text { NOP }>7 \\
\text { NLOC }>20 \\
V G>5 \\
\text { NBD }>6\end{array}$ & Tidak terdeteksi \\
\hline 8 & - & Tidak terdeteksi \\
\hline
\end{tabular}

Tabel XIV dan XV menampilkan hasil dari inspeksi kode dan perhitungan software metric yang didapat dari kode sumber hasil Gambar 3. Class Diagram Kode Versi-2. Hasil dari Tabel XIV dan XV dirangkun dalam Tabel XVI 
dengan menandakan terdeteksi atau tidak terdeteksi suatu code inspection pada sumber kode kelas yang dibuat.

TABEL XVI

HASIL DARI SUMBER KODE VERSI-2 E-COMMERCE

\begin{tabular}{|c|c|c|c|c|c|c|c|c|c|c|c|c|c|}
\hline $\begin{array}{l}\mathbf{N} \\
\mathbf{0}\end{array}$ & $\begin{array}{l}\mathbf{J} \\
\mathbf{n} \\
\mathbf{S} \\
\end{array}$ & $\begin{array}{l}\mathbf{E} \\
\text { C } \\
\text { B }\end{array}$ & $\mathbf{K}$ & $\mathbf{J}$ & $\mathbf{M}$ & B & $\mathbf{C}$ & $\begin{array}{l}\mathbf{J} \\
\mathbf{I}\end{array}$ & $\begin{array}{l}\mathbf{J} \\
\mathbf{D}\end{array}$ & $\mathbf{S}$ & $\begin{array}{l}\text { B } \\
\text { D }\end{array}$ & $\begin{array}{l}\text { Jl } \\
\text { D }\end{array}$ & $\begin{array}{c}\text { Hasil } \\
\text { Detek } \\
\text { si } \\
\end{array}$ \\
\hline \multirow[b]{2}{*}{1} & $\mathrm{~T}$ & 1 & 0 & 0 & 0 & 0 & 0 & 0 & 0 & 0 & 0 & 0 & 1 \\
\hline & $\begin{array}{l}\mathrm{S} \\
\mathrm{W}\end{array}$ & 1 & 0 & 0 & 0 & 0 & 0 & 0 & 0 & 0 & 0 & 0 & 1 \\
\hline \multirow[b]{2}{*}{2} & $\mathrm{~T}$ & 0 & 0 & 0 & 0 & 0 & 0 & 0 & 0 & 0 & 0 & 0 & 0 \\
\hline & $\begin{array}{l}\mathrm{S} \\
\mathrm{W}\end{array}$ & 0 & 0 & 0 & 0 & 0 & 0 & 0 & 0 & 0 & 0 & 0 & 0 \\
\hline \multirow[b]{2}{*}{3} & $\mathrm{~T}$ & 0 & 0 & 0 & 0 & 0 & 0 & 0 & 0 & 0 & 0 & 0 & 0 \\
\hline & $\begin{array}{l}\mathrm{S} \\
\mathrm{W}\end{array}$ & 0 & 0 & 0 & 0 & 0 & 0 & 0 & 0 & 0 & 0 & 0 & 0 \\
\hline \multirow[b]{2}{*}{4} & $\mathrm{~T}$ & 0 & 0 & 0 & 0 & 0 & 0 & 0 & 0 & 0 & 0 & 0 & 0 \\
\hline & $\begin{array}{l}\mathrm{S} \\
\mathrm{W}\end{array}$ & 0 & 0 & 0 & 0 & 0 & 0 & 0 & 0 & 0 & 0 & 0 & 0 \\
\hline \multirow[b]{2}{*}{5} & $\mathrm{~T}$ & 0 & 0 & 0 & 0 & 0 & 0 & 0 & 0 & 0 & 0 & 0 & 0 \\
\hline & $\begin{array}{l}\mathrm{S} \\
\mathrm{W}\end{array}$ & 0 & 0 & 0 & 0 & 0 & 0 & 0 & 0 & 0 & 0 & 0 & 0 \\
\hline \multirow[b]{2}{*}{6} & $\mathrm{~T}$ & 1 & 0 & 0 & 0 & 0 & 0 & 0 & 0 & 0 & 1 & 0 & 2 \\
\hline & $\begin{array}{l}\mathrm{S} \\
\mathrm{W}\end{array}$ & 0 & 0 & 0 & 0 & 0 & 0 & 0 & 0 & 0 & 0 & 0 & 0 \\
\hline \multirow[b]{2}{*}{7} & $\mathrm{~T}$ & 1 & 0 & 0 & 0 & 0 & 0 & 0 & 0 & 0 & 0 & 0 & 1 \\
\hline & $\begin{array}{l}\mathrm{S} \\
\mathrm{W}\end{array}$ & 0 & 0 & 0 & 0 & 0 & 0 & 0 & 0 & 0 & 0 & 0 & 0 \\
\hline \multirow[b]{2}{*}{8} & $\mathrm{~T}$ & 0 & 0 & 0 & 0 & 0 & 0 & 0 & 0 & 0 & 0 & 0 & 0 \\
\hline & $\begin{array}{l}\mathrm{S} \\
\mathrm{W}\end{array}$ & 0 & 0 & 0 & 0 & 0 & 0 & 0 & 0 & 0 & 0 & 0 & 0 \\
\hline & & & & & & & & & & \multicolumn{3}{|c|}{ Total } & 5 \\
\hline & & & & & & & & & & \multicolumn{3}{|c|}{ Rata-Rata } & $\begin{array}{r}0.0284 \\
09091\end{array}$ \\
\hline & $\begin{array}{l}\text { era } \\
\text { idal } \\
\text { Tool } \\
\text { : So } \\
\text { B: }\end{array}$ & $\begin{array}{l}\text { an } \\
\text { ksi } \\
\text { Ter }\end{array}$ & $\begin{array}{l}\text { teks } \\
\text { Met } \\
\text { Com }\end{array}$ & $\begin{array}{l}\text { si } \\
\text { tric } \\
\text { mer }\end{array}$ & ceB & & & $\begin{array}{l}\text { Kete } \\
\text { M: k } \\
\text { 3: ke } \\
\text { C: ke } \\
\text { l: ke } \\
\text { D: } \\
\text { : ke } \\
\text { BD: } \\
\text { lD: }\end{array}$ & $\begin{array}{l}\text { ran } \\
\text { las } \\
\text { las } \\
\text { las } \\
\text { las } \\
\text { elas } \\
\text { as } \\
\text { ela } \\
\text { tela }\end{array}$ & $\begin{array}{l}\text { an: } \\
\text { Merl } \\
\text { ara } \\
\text { ustc } \\
\text { dal } \\
\text { Jual } \\
\text { ettin } \\
\text { Bar } \\
\text { Jua }\end{array}$ & $\begin{array}{l}\text { g } \\
\text { mer } \\
\text { Deta } \\
\text { g } \\
\text { angI } \\
\text { DA }\end{array}$ & & \\
\hline
\end{tabular}

D. Hasil Inspeksi Kode dan Perhitungan Software Metric pada Code Versi - 3

Gambar 3. Class Diagram Kode ini menggambarkan hasil pemisahan ManagedBean sesuai dengan fungsi passing data antar XHTML serta untuk refactoring Feature Envy dan God Class pada kelas ManageBean. Dari refactoring ini terdapat dua kelas ManageBean yang terdapat pada paket bean yang berfungsi sebagai kelas yang mengelola passing data ke XHTML dan pengelola alur data ke EJB.

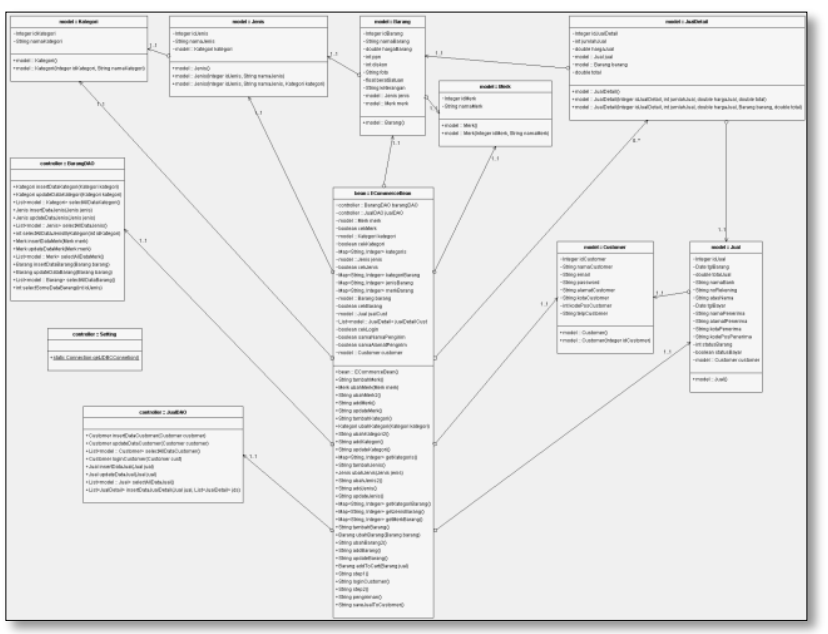

Gambar 4. Class Diagram Kode Versi-3

TABEL XVII

HASIL INSPKESI KODE PADA SUMBER KODE VERSI-3 E-COMMERCE

\begin{tabular}{|c|l|l|}
\hline \multirow{2}{*}{ No } & \multicolumn{2}{|c|}{ Code Inspection Tools } \\
\cline { 2 - 3 } & Nama Tools & \multicolumn{1}{c|}{ Hasil } \\
\hline 1 & PMD & $\begin{array}{l}\text { Kelas ECommerceBean terdeteksi } \\
\text { God Class }\end{array}$ \\
\cline { 2 - 3 } & JDeodorant & $\begin{array}{l}\text { Kelas ECommerceBean terdeteksi } \\
\text { God Class dengan refactoring } \\
\text { Extract Class; }\end{array}$ \\
\hline 2 & $\begin{array}{l}\text { Dead Code } \\
\text { Detector, } \\
\text { PMD, } \\
\text { Elimination } \\
\text { by IDE }\end{array}$ & Tidak terdeteksi \\
\hline 3 & Checkstyle & Tidak terdeteksi \\
\hline 4 & - & Tidak terdeteksi \\
\hline 5 & - & Tidak terdeteksi \\
\hline 6 & $\begin{array}{l}\text { JDeodorant } \\
\text { Kelas BarangDAO terdeteksi } \\
\text { Feature Envy }\end{array}$ \\
\hline 7 & $\begin{array}{l}\text { JDeodorant } \\
\text { Kelas ECommerceBean dan } \\
\text { BarangDAO terdeteksi Long Method }\end{array}$ \\
\hline 8 & $\begin{array}{l}\text { Dead Code } \\
\text { Detector, } \\
\text { PMD, } \\
\text { Elimination } \\
\text { by IDE }\end{array}$ & \begin{tabular}{l} 
Tidak terdeteksi \\
\hline
\end{tabular} \\
\hline
\end{tabular}

TABEL XVIII

Hasil Perhitungan SoftWARE METRIC PADA SuMber Kode VERSI-3 ECOMMERCE

\begin{tabular}{|c|l|l|}
\hline \multirow{2}{*}{ No } & \multicolumn{2}{|c|}{ Software Metrics } \\
\cline { 2 - 3 } & \multicolumn{1}{|c|}{ Nilai Deteksi } & \multicolumn{1}{|c|}{ Nilai Hasil Pengukuran } \\
\hline 1 & $\begin{array}{l}\text { a. WMC }>47 \\
\text { b. NOF }>15\end{array}$ & $\begin{array}{l}\text { Kelas ECommerceBean: } \\
\text { terdeteksi God Class }\end{array}$ \\
\hline
\end{tabular}




\begin{tabular}{|c|c|c|}
\hline \multirow{3}{*}{ No } & \multicolumn{2}{|c|}{ Software Metrics } \\
\hline & Nilai Deteksi & Nilai Hasil Pengukuran \\
\hline & $\begin{array}{l}\text { c. } \text { ATFD }>5 \\
\text { d. } \text { TCC }<0.33\end{array}$ & $\begin{array}{l}\text { a. } \mathrm{WMC}=60 \\
\text { b. } \mathrm{NOF}=19 \\
\text { c. } \mathrm{ATFD}=66 \\
\text { d. } \text { TCC }=0.1\end{array}$ \\
\hline 2 & - & Tidak terdeteksi \\
\hline 3 & $\mathrm{NOP}>7$ & Tidak terdeteksi \\
\hline 4 & $\begin{array}{l}\text { a. } \text { LOC }>300 \& \\
\text { long methods }>5 \text {. } \\
\text { b. } \text { DIT }>5 \\
\text { c. } \text { CBO }>10\end{array}$ & Tidak terdeteksi \\
\hline 5 & $\begin{array}{l}\text { a. } \mathrm{NOM}=0 \\
\text { b. } \mathrm{LOC}<100 \& \\
\text { WMC }<=2\end{array}$ & Tidak terdeteksi \\
\hline 6 & $\begin{array}{l}\text { a. } \mathrm{CBO}>5 \\
\text { b. } \mathrm{LCOM}>2\end{array}$ & Tidak terdeteksi \\
\hline 7 & $\begin{array}{l}\text { a. } \mathrm{NOP}>7 \\
\text { b. } \mathrm{NLOC}>20 \\
\text { c. } \mathrm{VG}>5 \\
\text { d. } \mathrm{NBD}>6\end{array}$ & Tidak terdeteksi \\
\hline 8 & - & Tidak terdeteksi \\
\hline
\end{tabular}

Tabel XVII dan XVIII menampilkan hasil dari inspeksi kode dan perhitungan software metric yang didapat dari kode sumber hasil Gambar 4. Class Diagram Kode Versi-3. Hasil dari Tabel XVII dan XVIII dirangkun dalam Tabel XIX dengan menandakan terdeteksi atau tidak terdeteksi suatu code inspection pada sumber kode kelas yang dibuat.

TABEL XIX

HASIL DARI SUMBER KODE KODE VERSI-3 E-COMMERCE

\begin{tabular}{|c|c|c|c|c|c|c|c|c|c|c|c|c|c|}
\hline $\begin{array}{l}\mathbf{N} \\
\mathbf{0}\end{array}$ & $\begin{array}{l}\mathbf{J} \\
\mathbf{n} \\
\mathbf{S} \\
\end{array}$ & $\begin{array}{l}\mathbf{E} \\
\mathbf{C} \\
\mathbf{B}\end{array}$ & $\mathbf{K}$ & $\mathbf{J}$ & $\mathbf{M}$ & B & $\mathbf{C}$ & $\begin{array}{l}\mathbf{J} \\
\mathbf{I}\end{array}$ & $\begin{array}{l}\mathbf{J} \\
\mathbf{D}\end{array}$ & $\mathbf{S}$ & $\begin{array}{l}\text { B } \\
\text { D }\end{array}$ & $\begin{array}{l}\text { Jl } \\
\text { D }\end{array}$ & $\begin{array}{c}\text { Hasil } \\
\text { Detek } \\
\text { si } \\
\end{array}$ \\
\hline \multirow[b]{2}{*}{1} & $\mathrm{~T}$ & 1 & 0 & 0 & 0 & 0 & 0 & 0 & 0 & 0 & 0 & 0 & 1 \\
\hline & $\begin{array}{l}\mathrm{S} \\
\mathrm{W}\end{array}$ & 1 & 0 & 0 & 0 & 0 & 0 & 0 & 0 & 0 & 0 & 0 & 1 \\
\hline \multirow[b]{2}{*}{2} & $\mathrm{~T}$ & 0 & 0 & 0 & 0 & 0 & 0 & 0 & 0 & 0 & 0 & 0 & 0 \\
\hline & $\begin{array}{l}S \\
W\end{array}$ & 0 & 0 & 0 & 0 & 0 & 0 & 0 & 0 & 0 & 0 & 0 & 0 \\
\hline \multirow[b]{2}{*}{3} & $\mathrm{~T}$ & 0 & 0 & 0 & 0 & 0 & 0 & 0 & 0 & 0 & 0 & 0 & 0 \\
\hline & $\begin{array}{l}\mathrm{S} \\
\mathrm{W}\end{array}$ & 0 & 0 & 0 & 0 & 0 & 0 & 0 & 0 & 0 & 0 & 0 & 0 \\
\hline \multirow[b]{2}{*}{4} & $\mathrm{~T}$ & 0 & 0 & 0 & 0 & 0 & 0 & 0 & 0 & 0 & 0 & 0 & 0 \\
\hline & $\begin{array}{l}\mathrm{S} \\
\mathrm{W}\end{array}$ & 0 & 0 & 0 & 0 & 0 & 0 & 0 & 0 & 0 & 0 & 0 & 0 \\
\hline \multirow[b]{2}{*}{5} & $\mathrm{~T}$ & 0 & 0 & 0 & 0 & 0 & 0 & 0 & 0 & 0 & 0 & 0 & 0 \\
\hline & $\begin{array}{l}\mathrm{S} \\
\mathrm{W}\end{array}$ & 0 & 0 & 0 & 0 & 0 & 0 & 0 & 0 & 0 & 0 & 0 & 0 \\
\hline \multirow[b]{2}{*}{6} & $\mathrm{~T}$ & 0 & 0 & 0 & 0 & 0 & 0 & 0 & 0 & 0 & 1 & 0 & 1 \\
\hline & $\begin{array}{l}\mathrm{S} \\
\mathrm{W}\end{array}$ & 0 & 0 & 0 & 0 & 0 & 0 & 0 & 0 & 0 & 0 & 0 & 0 \\
\hline 7 & $\mathrm{~T}$ & 1 & 0 & 0 & 0 & 0 & 0 & 0 & 0 & 0 & 0 & 0 & 1 \\
\hline
\end{tabular}

\begin{tabular}{|c|c|c|c|c|c|c|c|c|c|c|c|c|c|}
\hline \multirow[t]{2}{*}{$\begin{array}{l}\mathbf{N} \\
\mathbf{o}\end{array}$} & $\begin{array}{l}\mathbf{J} \\
\mathbf{n} \\
\mathbf{S}\end{array}$ & $\begin{array}{l}\mathbf{E} \\
\mathbf{C} \\
\mathbf{B}\end{array}$ & $\mathbf{K}$ & $\mathbf{J}$ & $\mathbf{M}$ & B & $\mathbf{C}$ & $\begin{array}{l}\mathbf{J} \\
\mathbf{I}\end{array}$ & $\begin{array}{l}\text { J } \\
\text { D }\end{array}$ & $\mathbf{S}$ & $\begin{array}{l}\text { B } \\
\text { D }\end{array}$ & $\begin{array}{l}\text { Jl } \\
\text { D }\end{array}$ & $\begin{array}{c}\text { Hasil } \\
\text { Detek } \\
\text { si }\end{array}$ \\
\hline & $\begin{array}{l}\mathrm{S} \\
\mathrm{W}\end{array}$ & 0 & 0 & 0 & 0 & 0 & 0 & 0 & 0 & 0 & 0 & 0 & 0 \\
\hline \multirow[b]{2}{*}{8} & $\mathrm{~T}$ & 0 & 0 & 0 & 0 & 0 & 0 & 0 & 0 & 0 & 0 & 0 & 0 \\
\hline & $\begin{array}{l}\mathrm{S} \\
\mathrm{W}\end{array}$ & 0 & 0 & 0 & 0 & 0 & 0 & 0 & 0 & 0 & 0 & 0 & 0 \\
\hline & & & & & & & & & & \multicolumn{3}{|c|}{ Total } & 4 \\
\hline & & & & & & & & & & \multicolumn{3}{|c|}{ Rata-Rata } & $\begin{array}{r}0.0227 \\
27273\end{array}$ \\
\hline & $\begin{array}{l}\text { ter: } \\
\text { Terd } \\
\text { Tida } \\
\text { Tool } \\
\text { : So } \\
\text { B: k } \\
\text { kela } \\
\text { elas } \\
\text { kela }\end{array}$ & $\begin{array}{l}\text { war } \\
\text { as } \\
\text { Kate } \\
\text { enis }\end{array}$ & $\begin{array}{l}\text { Me } \\
\text { om } \\
\text { ori }\end{array}$ & me & ceB & & & $\begin{array}{l}\text { Kete } \\
\text { B: ke } \\
\text { C: ke } \\
\text { l: ke } \\
\text { ID: k } \\
\text { S: ke } \\
\text { BD: } \\
\text { ID: }\end{array}$ & $\begin{array}{l}\text { ang } \\
\text { las } \\
\text { las } \\
\text { las J } \\
\text { elas } \\
\text { as S } \\
\text { ela } \\
\text { ela }\end{array}$ & $\begin{array}{l}\text { an: } \\
\text { ara } \\
\text { ust } \\
\text { dal } \\
\text { Jual } \\
\text { ettir } \\
\text { Ba } \\
\text { Jua }\end{array}$ & $\begin{array}{l}\text { Deta } \\
\text { g } \\
\text { ang } \\
\text { IDA }\end{array}$ & $\mathrm{AO}$ & \\
\hline
\end{tabular}

\section{E. Hasil Inspeksi Kode dan Perhitungan Software Metric pada Code Versi - 4}

Gambar 5. Class Diagram Kode Versi-4 ini menggambarkan hasil penerapan framework Java Persistence API (JPA) untuk pengelolaan antara Java dan basis data serta untuk refactoring Long Method pada kelas controller. Dari refactoring ini terdapat dua kelas controller yang terdapat pada paket control yang berfungsi sebagai kelas yang mengelola passing data ke XHTML dan pengelola alur data ke EJB.

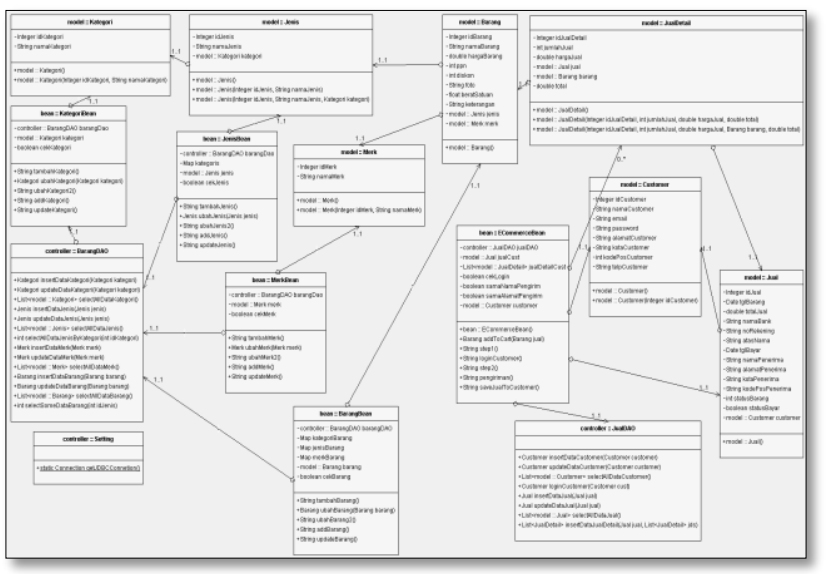

Gambar 5. Class Diagram Kode Versi-4 
TABEL XX

HASIL INSPKESI KODE PADA SUMBER KODE VERSI-4 E-COMMERCE

\begin{tabular}{|r|l|l|}
\hline \multirow{2}{*}{ No } & \multicolumn{2}{|c|}{ Code Inspection Tools } \\
\cline { 2 - 3 } & \multicolumn{1}{|c|}{ Nama Tools } & \multicolumn{1}{c|}{ Hasil } \\
\hline 1 & PMD & Tidak terdeteksi \\
\cline { 2 - 3 } & JDeodorant & $\begin{array}{l}\text { Kelas BarangBean } \\
\text { terdeteksi God Class } \\
\text { dengan refactoring Extract } \\
\text { Class }\end{array}$ \\
\hline 2 & $\begin{array}{l}\text { Dead Code Detector, } \\
\text { PMD, Elimination by } \\
\text { IDE }\end{array}$ & Tidak terdeteksi \\
\hline 3 & Checkstyle & Tidak terdeteksi \\
\hline 4 & - & Tidak terdeteksi \\
\hline 5 & - & Tidak terdeteksi \\
\hline 6 & JDeodorant & $\begin{array}{l}\text { Kelas BarangDAO } \\
\text { terdeteksi Feature Envy }\end{array}$ \\
\hline 7 & JDeodorant & $\begin{array}{l}\text { Kelas BarangDAO } \\
\text { terdeteksi Long Method }\end{array}$ \\
\hline 8 & $\begin{array}{l}\text { Dead Code Detector, } \\
\text { PMD, Elimination by } \\
\text { IDE }\end{array}$ & \begin{tabular}{l} 
Tidak terdeteksi \\
\hline
\end{tabular}
\end{tabular}

TABEL XXI

Hasil Perhitungan SoftWare METRIC PADA Sumber Kode VERSI-4 ECOMMERCE

\begin{tabular}{|c|l|l|}
\hline \multirow{2}{*}{ No } & \multicolumn{2}{|c|}{ Software Metrics } \\
\cline { 2 - 3 } & \multicolumn{1}{|c|}{ Nilai Deteksi } & Nilai Hasil Pengukuran \\
\hline 1 & $\begin{array}{l}\text { WMC }>47 \\
\text { NOF }>15 \\
\text { ATFD }>5 \\
\text { TCC }<0.33\end{array}$ & Tidak terdeteksi \\
\hline 2 & - & \\
\hline 3 & NOP $>7$ & Tidak terdeteksi \\
\hline 4 & $\begin{array}{l}\text { LOC }>300 \& \text { long } \\
\text { methods }>5 \\
\text { DIT }>5 \\
\text { CBO }>10\end{array}$ & Tidak terdeteksi \\
\hline 5 & $\begin{array}{l}\text { NOM }=0 \\
\text { LOC }<100 \& \text { WMC }<=2\end{array}$ & Tidak terdeteksi \\
\hline 6 & $\begin{array}{l}\text { CBO }>5 \\
\text { LCOM }>2\end{array}$ & Tidak terdeteksi \\
\hline 7 & $\begin{array}{l}\text { NOP }>7 \\
\text { NLOC }>20 \\
\text { VG }>5 \\
\text { NBD }>6\end{array}$ & Tidak terdeteksi \\
\hline 8 & & \\
\hline & & Tidak terdeteksi \\
\hline
\end{tabular}

Tabel XX dan XXI menampilkan hasil dari inspeksi kode dan perhitungan software metric yang didapat dari kode sumber hasil Gambar 5. Class Diagram Kode Versi-4. Hasil dari Tabel XX dan XXI dirangkun dalam Tabel XXII dengan menandakan terdeteksi atau tidak terdeteksi suatu code inspection pada sumber kode kelas yang dibuat.
TABEL XXII

HASIL DARI SUMBER KODE VERSI-4 E-COMMERCE

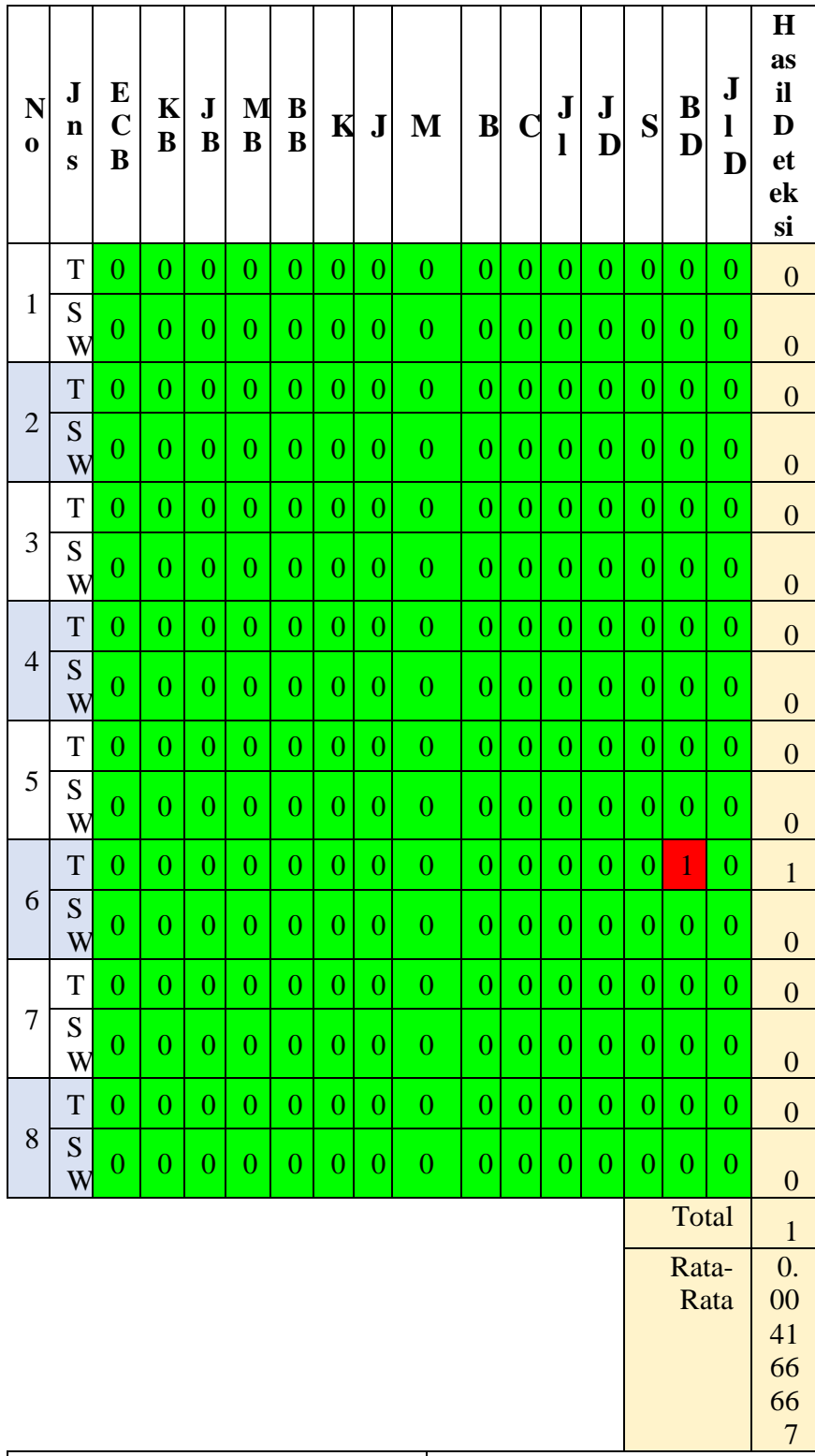

\section{Keterangan:}

1: Terdeteksi

0: Tidak Terdeteksi

$\mathrm{T}$ : Tools

SW: Software Metric ECB: kelas ECommerceBean KB: kelas KategoriBean JB: kelas JenisBean MB: kelas MerkBean BB: kelas BarangBean $\mathrm{K}$ : kelas Kategori

Keterangan:
J: kelas Jenis
M: kelas Merk
B: kelas Barang
C: kelas Customer
Jl: kelas Jual
JD: kelas JualDetail
S: kelas Setting
BD: kelas BarangDAO
J1D: kelas JualDAO

Dikarenakan menggunakan teknik MVC design pattern maka pada kelas BarangDAO terdeteksi feature envy oleh JDeodorant. Feature envy menunjukkan method satu kelas yang nampaknya lebih ditujukan pada atribut kelas lain dari 
posisi sekarang atau disebut juga method mengakses data objek lain lebih banyak dari pada datanya sendiri [12] [24]. Dikarenakan teknik MVC mengharuskan memisahkan Java kelas untuk model atau kelas yang berisi atribut dan method setter-getter dengan Java kelas yang mengelola proses bisnis dari kelas model yang berarti kelas memiliki method yang mengakses data objek lain yaitu Java kelas model maka feature envy yang di deteksi ini tidak ada dilakukan refactoring sebab sesuai dengan penggunaan MVC design pattern dan secara hasil perhitungan software metrics tidak terdeteksi adanya feature envy.

\section{KESIMPULAN DAN SARAN UNTUK MASA DEPAN}

Berdasarkan hasil evaluasi, didapat kesimpulan code inspection tools PMD, Checkstyle, JDeodorant, dan Dead Code Detector dapat digunakan untuk inspeksi secara otomatis dengan kemapuan yang berbeda untuk setiap pendeteksiannya. Meskipun demikian dalam pendeteksian terhadap kode dalam mencari smell code dan anti pattern dari kode yang diinspeksinya ada baiknya penggunaan code inspection tools digunakan bersamaan dengan perhitungan software metric untuk mencari smell code dan anti pattern agar hasil lebih akurat dan dapat menentukan apakah perlu di-refactoring saat ini atau nanti atau memang tidak diperlukan refactoring. Setelah pendeteksian terhadap kode untuk menemukan smell code dan anti pattern, tidak semua hasil smell code dan anti pattern yang terdeteksi harus dilakukan refactoring sebab melalui hasil perhitungan nilai software metric-nya tidak menunjukkan adanya gejala terdapatnya smell code dan anti pattern serta penggunaan arsitektur atau pola design perangkat lunak yang digunakan diharuskan mengabaikan refactoring untuk smell code atau anti pattern yang terdeteksi. Contoh kasus pada evaluasi penelitian ini adalah MVC design pattern yang menngharuskan memisahkan fungsi model dan controller maka pada controller pasti akan menghasilkan smell code feature envy. Dari hasil deteksi kode sumber oleh code inspection tools PMD, Checkstyle, JDeodorant, dan Dead Code Detector juga didapat hasil:

1. Deteksi God Class dapat dilakukan oleh PMD dan JDeodorant dimana JDeodorant menampilkan hasil dengan memberikan saran untuk melakukan refactoring Extract Class.

2. Deteksi Lava Flow, Large Class, Lazy Class dan Dead Code tidak dapat dilakukan oleh code inspection tools yang digunakan.

3. Deteksi Long Parameter List dapat dilakukan oleh Checkstyle.

4. Deteksi Feature Envy dan Long Method dapat dilakukan oleh JDeodorant dimana JDeodorant menampilkan hasil deteksi Feature Envy dengan memberikan saran untuk melakukan Refactoring Move Method.

Pemilihan smell code dan anti pattern lebih lengkap lagi, seperti smell code yang terdiri dari 5 kategori, yaitu:
Bloaters, Object-Orientation Abusers, Change Preventers, Dispensables, dan Couplers serta mencakup semua anti pattern yang terdapat pada buku AntiPatterns-Refactoring Software, Architectures, and Projects in Crisis [21] sangat disarankan untuk pengembangan penelitian kedepannya.

\section{DAFTAR PUSTAKA}

[1] S. Velioglu and Y. E. Selçuk, "An Automated Code Smell and AntiPattern Detection Approach," Software Engineering Research and Applications, pp. 271-275, 2017.

[2] M. Noro and A. Sawada, "Software Architecture and Specification Model for Customizable Code Inspection Tools," Asia-Pacific Software Engineering Conference, pp. 230-237, 2015.

[3] N. Rutar, C. B. Almazan dan J. S. Foster, "A Comparison of Bug Finding Tools for Java," International Symposium on Software Reliability Engineering, 2004.

[4] "Checkstyle," [Online]. Available: http://checkstyle.sourceforge.net/. [5] pmd, "PMD/Java.," 2002. [Online]. Available: http://pmd.sourceforge.net/.

[6] nikolaos, "JDeodorant," [Online]. Available: https://users.encs.concordia.ca.

[7] M. Fowler, K. Beck, J. Brant, W. Opdyke and D. Roberts, Refactoring: improving the design of existing code, Addison-Wesley, 1999.

[8] F. Palomba, G. Bavota, R. Oliveto and A. D. Lucia, "Anti-Pattern Detection: Methods, Challenges, and Open Issues," 2014.

[9] E. M. Fagan, "Design and code inspections to reduce errors in program development," IBM Systems Journal, vol. 15, no. 3, pp. 182 211, 1976.

[10] E. S. Cho, M. S. Kim and S. D. Kim, "Component Metrics to Measure Component Quality," Software Engineering Conference, 2001. APSEC 2001. Eighth Asia-Pacific, pp. 419-426, 2001.

[11] E. Tilevich and Y. Smaragdakis, "Binary refactoring: improving code behind the scenes," in Software Engineering, 2005. ICSE 2005. Proceedings. 27th International Conference, Saint Louis, 2005.

[12] S. Kaur and S. Singh, "Influence of Anti-Patterns on Software Maintenance: A Review," ICAET, vol. 8887, p. 975, 2015.

[13] S. R. Chidamber and C. F. Kemerer, "A metrics Suite for Object Oriented Design," IEEE Transactions on Software Engineering, vol. 20, no. 6, pp. 476 - 493, 1994.

[14] D. W. Kurt, "The Software Maintainability Index Revisited," in Idaho National Engineering and Environmental Laboratory, 2001.

[15] R. S. Pressman, Software Engineering A Practitioner_s Approach, 7ed, 2010.

[16] F. R. Oppedijk, "Comparison of the SIG Maintainability Model," University of Amsterdam, 2008.

[17] N. E. Fenton, "Software Measurement: A Necessary Scientific Basis," in IEEE Transactions on Software Engineering, 1994.

[18] J. Rosenberg, "Some Misconceptions About Lines of Code," Fourth International Software Metrics Symposium, pp. 137-142, 1997.

[19] J. M. Bieman and B.-K. Kang, "Cohesion and Reuse in an ObjectOriented System," ACM Symposium on Software Reusability, 1995.

[20] F. A. Fontana, P. Braione and M. Zanoni, "Automatic detection of bad smells in code: An experimental assessment," Journal of Object Technology, vol. 11, no. 2, pp. 1-38, 2011.

[21] W. J. Brown, R. C. Malveau, H. W. ". McCormick and T. J. Mowbray, AntiPatterns, Refactoring Software, Architectures, and Projects in Crisis, Canada: John Wiley \& Sons, Inc., 1998.

[22] CAST, "Code Analysis Tools," 2017. [Online]. Available: http://www.castsoftware.com/products/code-analysis-tools. 
[23] J.-P. Ostberg and S. Wagner, "Do We Stop Learning from Our Mistakes When Using Automatic Code Analysis Tools An Experiment Proposal," User Evaluation for Software Engineering Researchers (USER), 2012, pp. 21-24, 2012.

[24] sourcemaking.com, "Code Smells," sourcemaking.com, 2007. [Online]. Available: https://sourcemaking.com/refactoring/smells.
[25] S. Kaur and D. R. Maini, "Analysis of Various Software Metrics Used To Detect Bad Smells," The International Journal Of Engineering And Science (IJES), pp. 15-19, 2016. 